TITLE:

\title{
Marine benthic community in Shirahama, southwestern Kii Peninsula, central Japan
}

\section{AUTHOR(S):}

OKANISHI, MASANORI; SENTOKU, ASUKA; FUJIMOTO, SHINTA; JIMI, NAOTO; NAKAYAMA, RYO; YAMANA, YUSUKE; YAMAUCHI, HIROKI; ... YAMAMOTO, KOHKI; MIYAZAKI, KATSUMI; ASAKURA, AKIRA

\section{CITATION:}

OKANISHI, MASANORI ...[et al]. Marine benthic community in Shirahama, southwestern Kii Peninsula, central Japan. Publications of the Seto Marine Biological Laboratory 2016, 44: $7-52$

\section{ISSUE DATE:}

2016-12-07

URL:

http://hdl.handle.net/2433/217458

RIGHT: 
Publ. Seto Mar. Biol. Lab., 44: 7-52, published online, 2016; published in print, 2018.

\title{
Marine benthic community in Shirahama, southwestern Kii Peninsula, central Japan
}

\author{
MASANORI OKANISHI ${ }^{\mathrm{a}, *}$, ASUKA SENTOKU ${ }^{\mathrm{b}}$, SHINTA FUJIMOTO ${ }^{\mathrm{c}}$, NAOTO JIMI ${ }^{\mathrm{d}}$, \\ RYO NAKAYAMA ${ }^{\mathrm{e}, \mathrm{f}}$, YUSUKE YAMANA ${ }^{\mathrm{g}}$, HIROKI YAMAUCHI ${ }^{\mathrm{f}}$, HAYATE TANAKA ${ }^{\mathrm{h}, \mathrm{i}}$, \\ TETSUYA KATO ${ }^{j}$, SHO KASHIO ${ }^{k}$, DAISUKE UYENO ${ }^{1}$, KOHKI YAMAMOTO ${ }^{f}$, \\ KATSUMI MIYAZAKI $^{\mathrm{m}}$ AND AKIRA ASAKURA ${ }^{\mathrm{f}, \mathrm{j}}$ \\ ${ }^{*}$ a College of Science, Ibaraki University, 2-1-1 Bunkyo, Mito, Ibaraki, 310-8512, Japan \\ ${ }^{\mathrm{b}}$ School of Earth Science, The University of Queensland, St. Lucia, QLD 4072, Australia \\ ${ }^{c}$ Research Center for Marine Biology, Graduate School of Life Sciences, Tohoku University, \\ 9 Sakamoto Asamushi, Aomori 039-3501, Japan \\ ${ }^{\mathrm{d}}$ Department of Natural History Sciences, Graduate School of Science, Hokkaido University, \\ Kita 10 Nishi 8, Sapporo 060-0810, Japan \\ ${ }^{\mathrm{e}}$ Department of Zoology, Division of Biological Science, Graduate School of Science, Kyoto University, \\ Kitashirakawa, Oiwake-cho, Sakyo-ku, Kyoto 606-8502, Japan \\ ${ }^{\mathrm{f}}$ Seto Marine Biological Laboratory, Field Science Education and Research Center, Kyoto University, \\ 459 Shirahama, Nishimuro, Wakayama 649-2211, Japan \\ ${ }^{g}$ Wakayama Prefectural Museum of Natural History, 370-1 Funao, Kainan, Wakayama 642-0001, Japan \\ ${ }^{\mathrm{h}}$ Department of Biological Sciences, Graduate School of Science, The University of Tokyo, \\ 7-3-1, Hongo, Bunkyo-ku, Tokyo 113-0033, Japan \\ ${ }^{\mathrm{i}}$ National Museum of Nature and Science, 4-1-1 Amakubo, Tsukuba, Ibaraki 305-0005, Japan \\ ${ }^{j}$ Shirahama Aquarium, Kyoto University, 459 Shirahama, Nishimuro, Wakayama 649-2211, Japan \\ ${ }^{\mathrm{k}}$ Natural History Museum, Kishiwada City, 6-5 Sakai-cho, Kishiwada, Osaka 596-0072, Japan \\ ${ }^{1}$ Graduate School of Science and Engineering, Kagoshima University, 1-21-35 Korimoto, Kagoshima 890-0065, Japan \\ ${ }^{\mathrm{m}}$ Department of Environmental Science, Faculty of Science, Niigata University, \\ 8050 Ikarashi 2-no-cho, Niigata 950-2181, Japan \\ *Corresponding author: mokanishi@teuru-mozuru.com
}

\begin{abstract}
We herein present the results of a survey which assessed the benthic fauna from subtidal to continental shelf depth in the Shirahama area from 2012 to 2016. Our research resulted in the identification of 132 species from 75 families in seven phyla, Cnidaria, Annelida, Tardigrada, Arthropoda, Mollusca, Echinodermata and Chordata. This includes 24 newly recorded species to Shirahama. Two species were also new records for Japanese waters. Furthermore, six undescribed species and five potentially undescribed species were recorded. We provide a selection of relevant photos for future taxonomic studies and monitoring of environmental changes.
\end{abstract}

Keywords: Seto Marine Biological Laboratory, Kii Peninsula, Benthos, Marine biodiversity 


\section{Introduction}

Japanese coastal area is a global biodiversity hot spot and high number of marine species are recorded (Fujikura et al., 2010). Numerous marine benthic surveys have been conducted along the Japanese coast. For example, from 1997 to 2014, National Science Museum, Tokyo (NSMT; currently referred as National Museum of Nature and Science) has carried out deep-sea taxonomic surveys in Suruga Bay, Tosa Bay, off Nansei Islands, off Tohoku District and in the Sea of Japan. The study area covered most of the Japanese coast except for Hokkaido. The NSMT has sampled depth as shallow as approximately $50 \mathrm{~m}$ but primary survey depth ranged from $100 \mathrm{~m}$ and deeper (NSMT, 1997; 2001; 2005; 2009; 2014). Water depth is an important environmental parameter, and comparative analysis between shallow and deep-water benthic communities is an active area of research (Sanders, 1968; Gray et al., 1997; Rex et al., 2000; Levin et al., 2001). But in many cases, the study areas have been limited to either the shallow (subtidal to littoral) or deep (more than $100 \mathrm{~m}$ ) depths. 'Intermediate depths (approximately 40-100 m)' have been poorly studied in Japan. Recently, the JAMBIO (Japanese Association for Marine Biology) organized ten coastal marine taxonomic surveys, operated from the Shimoda Marine Research Center, University of Tsukuba and Misaki Marine Biological Station, The University of Tokyo, in order to study the marine benthic fauna of Sagami Bay (Namikawa, 2008; Nakano et al., 2015). Nakano et al. (2015) undertook surveys of this region, and although list of species and detailed locality information were not provided, at least 250 species including 50 likely undescribed species were collected from broad depth range $(5-750 \mathrm{~m})$.

In these studies, photographs of animals were provided for limited numbers of taxa. Photographs support identifications of the animals, and provide confirmation of the taxonomy. They are also useful for recognizing misidentifications, undescribed species and cryptic species for future studies. Because the color of living specimens is lost in dead and preserved specimens, high resolution photographs displaying the color of live specimens is essential to recognize the intraspecific variation, nuptial coloration and the discovery of new characters. Thus, ongoing and comprehensive assessments of marine benthic diversity should include more comprehensive sampling of intermediate, poorly sampled depths, more intensive color imagery, and well-maintained databases of sampled localities.

Shirahama is a temperate marine setting but is influenced by the Kuroshio Current, making its fauna more diverse than those of other adjacent areas on Kii Strait and Kumano Sea (Ohgaki, 2011) (Fig. 1A). It is an area which remains insufficiently understood in spite of prior research surveys. Seto Marine Biological Laboratory (SMBL) of Kyoto University is located in Shirahama, Wakayama Prefecture, southwestern Kii Peninsula where Kii Strait meets the Pacific Ocean. Many snorkeling and SCUBA diving surveys have revealed the rich marine fauna known from subtidal and littoral settings around Shirahama (e.g. Fauvel, 1936; Yamamoto, 1971; Habe, 1976; Yanagisawa, 1978; Fukano, 1980; Kuwamura, 1980; Irimura, 1981; Noda, 1987; Fujimoto et al., 2013; Yoshida et al., 2013; Zayasu et al., 2013). Most survey depths have been limited to depths shallower than $30 \mathrm{~m}$. Deeper-water fauna present off Shirahama has been sampled based on fishing bycatch from sublittoral and continental shelf settings taken at Sakai Fishing Port in Minabe, northern part of Tanabe Bay (e.g. Utinomi, 1952; Irimura, 1981) (Fig. 1). Bieri and Tokioka (1968) used Dragonnet, a opening-closing quantitative trawl in southern Tanabe Bay and sampled species habitats from shallow-waters to $100 \mathrm{~m}$ (Bieri and Tokioka, 1968). However, the coordinates and depth of the sampling localities were not specified and the depths were mostly restricted to shallower than $100 \mathrm{~m}$.

In this study, we conducted successive investigations in Shirahama using two SMBL research vessels, the 'Janthina' and the 'Zoea'. The purpose of the investigations was to obtain baseline benthic community information. To provide a 'detailed' inventory, the present survey sought to sample localities covered a broad depth gradient (4-295 m); using standardized protocols for dredges and bottom mud samplers. A part of the collected material was examined and the specimens were identified to species level whenever possible. Photographs of animals with value for recording were taken for future comparative research in this area (Fig. $1)$. 


\section{Materials and Methods}

We conducted fourteen investigations with Janthina (Fig. 2A) and one investigation with Zoea (Fig. 2B) at 47 sampling sites, covering a broad sampling area and depth range in Shirahama (Table 1; Fig. 1B). Shirahama Marine Research (SMR) numbers were tentatively assigned to all the sampling sites for this paper. Animals and bottom sediments were collected by using three types of dredges and one bottom sampler: a 50 cm-front biological dredge (Fig. 2C), a Smith Mcintyre bottom grab sampler (Fig. 2D), a Kamiya-type dredge (Fig. 2E) and a dredge for meio-benthos (Fig. 2F). After picking up relatively large mega-benthos (more than several centimeter), the sediment samples were processed at SMBL with appropriate sieves. In some sampling sites, at least SMR15-03-1 and SMR15-04-1, collection of meiobenthos were carried out by the method of Akiyama et al. (2008).

Fixation and identification of samples were performed by the researchers participating in the survey or SMBL personnel. Samples were basically fixed with 70-99\% ethanol. Holothuroidea (sea cucumber) specimens were fixed with $40-80 \%$ ethanol. All holothurian specimens were dissected, and the tentacles, anal appendages, Polian vesicles, stone canals, and calcareous rings were examined under a stereoscopic microscope (Nikon SMZ). To observe the morphology of the ossicles, small pieces of tissue were isolated from the body-wall integument, pedicels, tentacle and introvert. The tissue samples were dissolved in sodium hypochlorite solution ( $\mathrm{NaClO}, 5 \%$ ) under a compound microscope (Nikon Optiphot). The collected specimens and glass slides of their ossicles have been deposited in the Invertebrate Collection (INV) of the Wakayama Prefectural Museum of Natural History (WMNH), Kainan, Wakayama, Japan. Tardigrades were processed following methods outlined by Akiyama (2008). Filtered samples were directly fixed with $99 \%$ ethanol. To concentrate the sample, Ludox ${ }^{\circledR}$ HS-40 colloidal silica was used following Fujimoto (2015), a method modified from Burgess (2001). The specimens were sorted under a stereomicroscope and mounted in glycerol for phase-contrast microscopy (Olympus BX53). In Mollusca, living-specimens (represented as "A" in materials examined) were boiled to remove bodies and preserved in $99 \%$ ethanol. Specimens of dead-shells (represented as "D" in materials examined) were preserved at dry condition.

A subset of sampled animals was photographed alive and later fixed, numbered and labelled. Most specimens were stored at SMBL but some of the collections were deposited in the authors' institutions, museums or personal collections. All individuals were counted, but solitary corals which were account to over 50 individuals were not concretely counted.

\section{Taxonomic accounts}

\section{Phylum Cnidaria}

\section{General remarks}

We collected eight species from eight genera, six families of azooxanthellate solitary corals. Concrete numbers of fresh specimens were not counted in this study.

Class Anthozoa Ehrenberg, 1834

Subclass Hexacorallia Haeckel, 1866

Order Scleractinia Bourne, 1900

Family Anthemiphylliidae Vaughan, 1907

Genus Anthemiphyllia Pourtalès, 1878 


\section{MASANORI OKANISHI ET AL.}

1. Anthemiphyllia dentata (Alcock, 1902) (Fig. 3A, B)

Material examined. SMR15-02-2 (50<), SMR15-03-1 (50<), SMR15-07-2 $(50<*)$

Family Caryophylliidae Dana, 1846

Genus PremocyathusYabe and Eguchi, 1942

2. Premocyathus dentiformis (Alcock, 1902) (Fig. 3C, D)

Material examined. SMR15-03-1 (50<), SMR15-03-3 (50<), SMR15-07-2 (50<*)

Family Flabellidae Bourne, 1905

Genus Truncatoflabellum Cairns, 1989

3. Truncatoflabellum phoenix Cairns, 1995 (Fig. 3E, F)

Material examined. SMR15-02-2 (50<), SMR15-03-3 (50<), SMR15-04-1 (50<), SMR15-07-2 $(50<*)$

Family Micrabaciidae Vaughan, 1905

Genus Letepsammia Yabe and Eguchi, 1932

4. Letepsammia formosissima (Moseley, 1876) (Fig. 3G, H)

Material examined. SMR15-02-2 (50<), SMR15-03-1 (50<), SMR15-04-1 (50<), SMR15-07-2 $(50<*)$

Family Stenocyathidae Stolarski, 2000

Genus Truncatoguynia Cairns, 1989

5. Truncatoguynia irregularis Cairns, 1989 (Fig. 3I, J)

Material examined. SMR15-03-1 (50<), SMR15-07-2 (50<*)

Family Turbinoliidae Milne Edwards and Haime, 1848

Genus Deltocyathoides Yabe and Eguchi, 1932

6. Deltocyathoides orientalis (Duncan, 1876) (Fig. 3K, L)

Material examined. SMR15-03-1 (50<), SMR15-03-3 (50<), SMR15-04-1 (50<), SMR15-07-2 $(50<*)$.

Genus Idiotrochus Wells, 1935

7. Idiotrochus kikutii (Yabe and Eguchi, 1941) (Fig. 3M, N)

Material examined. SMR15-02-2 (50<), SMR15-03-1 (50<), SMR15-04-1 (50<), SMR15-07-2 $(50<*)$

Genus Peponocyathus Gravier, 1915

8. Peponocyathus folliculus (Pourtalès, 1868) (Fig. 3O, P)

Material examined. SMR15-03-1 (50<), SMR15-04-1 (50<), SMR15-07-2 (50<*) 


\section{BENTHIC FAUNA OF SHIRAHAMA}

\section{Phylum Mollusca}

\section{General remarks}

We collected 25 species from nineteen genera, fourteen families including two undescribed species (Cylindriscala sp. (Epitoniidae) and Gymnodoris sp. (Gymnodorididae)). Systematics follows Bouchet and Rocroi (2005), Bouchet et al. (2010), Oskars et al. (2015), Gosliner et al. (2015) and WoRMS (World Register of Marine Species) (2016), and species identification follows Nakayama (2000; 2003), Okutani (2000), Tsuchida (2000). However, we here refrain from using order level classification because it is under discussion. Most Japanese names follow Okutani (2000). It cannot be determined whether specimens of dead shell are distributed on the sampling site or not. But records of dead shells have been traditionally considered by molluscan researchers as distribution ranges (e.g. Hasegawa, 2001; 2005). Therefore we here record them in this paper.

Class Bivalvia Linnaeus, 1758

Superfamily Limopsoidea Dall, 1895

Family Limopsidae Dall, 1895

Genus Nipponolimopsis Habe, 1951

1. Nipponolimopsis azumana (Yokoyama, 1910) (Fig. 4A) [Jn: Maru-Shirasunagai]

Material examined. SMR15-02-2 (7*) (A), SMR15-04-1 (26) (A), SMR15-04-3 (6) (A)

2. Nipponolimopsis decussata (A. Adams, 1862) (Fig. 4B) [Jn: Mame-Shirasunagai]

Material examined. SMR15-05-2 (7*) (D)

Superfamily Tellinoidea Blainville, 1814

Family Tellinidae Blainville, 1814

Genus Cadella Dall, Bartsch and Rehder, 1938

3. Cadella delta (Yokoyama, 1922) (Fig. 4C) [Jn: Kusabi-Zara]

Material examined. SMR15-05-3 (12*) (D)

Genus Nitidotellina Scarlato, 1961

4. Nitidotellina lischkei Huber, Langleit and Kreipl, 2015 (Fig. 4D) [Jn : Uzu-Zakura]

Material examined. SMR15-04-3 (4) (A), SMR15-07-2 (7*) (A)

Family Veneridae Rafinesque, 1815

Genus Timoclea T. Brown, 1827

5. Timoclea minuta (Yokoyama, 1922) (Fig. 4E) [Jn: Adeyaka-Hime-Kanokoasari]

Material examined. SMR15-01-1 (5*) (A), SMR15-02-1 (5) (A), SMR15-07-2 (1) (A) SMR15-07-4

(12) (A)

Class Gastropoda Cuvier, 1795

Superfamily Buccinoidea Rafinesque, 1815

Family Fasciolariidae Gray, 1853

Genus Granulifusus Kuroda and Habe, 1954 


\section{MASANORI OKANISHI ET AL.}

6. Granulifusus niponicus (E. A. Smith, 1879) (Fig. 4F) [Jn: Arare-Naganishi]

Material examined. SMR15-04-1(5*) (D), SMR15-04-3 (5) (D), SMR15-07-1 (4) (D)

Superfamily Cerithioidea Fleming, 1822

Family Scaliolidae Jousseaume, 1912

Genus Finella A. Adams, 1860

7. Finella purpureoapicata Preston, 1905 (Fig. 4G) [Jn: Shima-Motsubo]

Material examined. SMR15-04-1 (6*) (D)

Superfamily Diaphanoidea Odhner, 1914 (1857)

Family Cylichnidae H. Adams and A. Adams, 1854

Genus Decorifer Iredale, 1937

8. Decorifer insignis (Pilsbry, 1904) (Fig. 4H) [Jn: Kometsubugai]

Material examined. SMR15-05-3 (6*) (D)

Superfamily Epitonioidea Berry, 1910 (1812)

Family Epitoniidae Berry, 1910 (1812)

Genus Amaea H. Adams and A. Adams, 1853

9. Amaea dorysa (Iredale, 1936) (Fig. 4I) [Jn: Dorisu-Arame-Itokake]

Material examined. SMR15-02-3 (1*) (A)

Genus Cylindriscala de Boury, 1909

10. Cylindriscala sp. (Fig. 4J)

Material examined. SMR15-04-1 (1*) (D)

Remarks. This undescribed species is also discovered by Hasegawa and Nakayama, and description is now under processing (Hasegawa and Nakayama, unpubl. data).

Genus Epitonium Röding, 1798

11. Epitonium angustum (Dunker, 1861) (Fig. 4K) [Jn: Toge-Hime-Nejigai]

Material examined. SMR15-05-2 (1) (A), SMR15-05-3 (2*) (D)

12. Epitonium heloris (Iredale, 1936) (Fig. 4L) [Jn: Hari-Daruma-Itokake]

Material examined. SMR15-07-1 (1*) (D)

13. Epitonium liliputanum (A. Adams, 1861) (Fig. 4M) [Jn: Kobito-Itokake]

Material examined. SMR15-04-1 (1*) (A), SMR15-07-1 (2) (D)

14. Epitonium rimbogai (Masahito and Habe, 1976) (Fig. 4N) [Jn: Rinbou-Itokake]

Material examined. SMR15-05-3 (1*) (D)

15. Epitonium simplex (Sowerby III, 1894) (Fig. 4O) [Jn: Maru-Hime-Nejigai]

Material examined. SMR15-05-3 (1*) (D) 


\section{BENTHIC FAUNA OF SHIRAHAMA}

16. Epitonium pallasi (Kiener, 1838) (Fig. 4P) [Jn: Kuwagata-Itokake]

Material examined. SMR15-02-2 (1*) (D)

Superfamily Muricoidea Rafinesque, 1815

Family Cystiscidae Stimpson, 1865

Genus Gibberula Swainson, 1840

17. Gibberula novemprovincialis (Yokoyama, 1928) (Fig. 4Q) [Jn: Ryugu-Kogomegai]

Material examined. SMR15-04-1 (6*) (D)

Superfamily Olivoidea Latreille, 1825

Family Olivellidae Troschel, 1869

Genus Olivella Swainson, 1831

18. Olivella fulgurata Adams and Reeve, 1850 (Fig. 4R) [Jn: Mushi-Botaru]

Material examined. SMR15-04-1 (8*) (D)

Superfamily Polyceroidea Alder and Hancock, 1845

Family Gymnodorididae Odhner, 1941

Genus Gymnodoris Stimpson, 1855

19. Gymnodoris sp. (Fig. 4S)

Material examined. SMR15-07-2 (1*) (A)

Remarks. This species is an undescribed species which is distinguished from the other congeners in having a crest-like protuberance on the posterior tail.

Superfamily Pyramidelloidea Gray, 1840

Family Pyramidellidae Gray, 1840

Genus Ptycheulimella Sacco, 1892

20. Ptycheulimella misella (Yokoyama, 1922) (Fig. 4T) [Jn: Mikazuki-Itokakegiri]

Material examined. SMR15-05-2 (9*) (D)

Genus Odetta de Folin, 1870

21. Odetta lirata (A. Adams, 1860) (Fig. 4U) [Jn: Itomaki-Kuchikire]

Material examined. SMR15-05-3 (19*) (A)

Superfamily Ringiculoidea Philippi, 1853

Family Ringiculidae Philippi, 1853

Genus Ringicula Deshayes, 1838

22. Ringicula tosaensis Habe, 1950 (Fig. 4V) [Jn: Tosa-Mame-Urashima]

Material examined. SMR15-04-1 (1*) (D), SMR15-04-4 (5) (D), SMR15-05-1 (1) (D)

Superfamily Trochoidea Rafinesque, 1815

Family Solariellidae Powell, 1951

Genus Microgaza Dall, 1881 


\section{MASANORI OKANISHI ET AL.}

23. Microgaza fulgens Dall, 1907 (Fig. 4W) [Jn: Hikari-Shitadami]

Material examined. SMR15-04-1 (1) (D), SMR15-04-2 (12*) (A), SMR15-04-3 (1) (D)

Genus Minolia A. Adams, 1860

24. Minolia subangulata Kuroda and Habe, 1952 (Fig. 4X) [Jn: Kado-Koshitaka-Shitadami]

Material examined. SMR15-04-1 (1) (D), SMR15-04-2 (17*) (A)

Remarks. This species has been recorded from Nansei Islands (Hasegawa, 2005), Bungo Channel (Hamada, 2010), Tosa Bay (Hasegawa, 2001), Mie Prefecture, (Ikebe, 2006), Rikucyu coast, (Habe, 1968). In faunistic surveys of molluscan shells in Wakayama Prefecture (Ikebe, 2006, 2008), this species was not recorded. Thus, this is the first record from off Shirahama.

Superfamily Vermetoidea Rafinesque, 1815

Family Vermetidae Rafinesque, 1815

Genus Thylacodes Guettard, 1770

25. Thylacodes medusa Pilsbry, 1891 (Fig. 4Y) [Jn: Hama-Kazura]

Material examined. SMR15-02-2 (1) (A), SMR15-04-1 (6*) (A), SMR15-04-2 (1) (A), SMR15-07-1

(1) (D)

\section{Phylum Annelida}

\section{General remarks}

We collected at least 41 species from 38 genera, 29 families, including two new records from Shirahama and three potentially undescribed species. Of these, it was impossible to identify 14 species and eleven genera to the species level due to their loss of taxonomic characters (e.g. prostomium and posterior segments) in process of sorting. Systematics follows Rouse and Pleijel (2001) and Japanese names follow Imajima (1996, 2001, 2007) and Uchida (1992). However, we here refrain from identifying order level classification because it is under discussion.

Family Phyllodocidae Örsted, 1843

Genus Nereiphylla Blainville, 1828

1. Nereiphylla castanea (Marenzeller, 1879) [Jn: Akeno-Sashiba]

Materials examined. SMR15-04-3 (1)

Family Syllidae Grube, 1850

2. Syllidae gen. sp.

Materials examined. SMR15-04-1 (6)

Family Hesionidae Grube, 1850

Genus Leocratides Ehlers, 1908

3. Leocratides $\mathrm{sp}$.

Materials examined. SMR15-04-1 (3) 


\section{BENTHIC FAUNA OF SHIRAHAMA}

Family Nereididae Blainville, 1818

4. Nereis or Neanthes sp.

Materials examined. SMR15-04-1 (1).

5. Tambalagamia fauveli Pillai, 1961 (Fig. 5A) [Jn: Kani-Gokai]

Materials examined. SMR15-04-4 (4*)

Remarks. This species is known from Manazuru Bay and the Ariake Sea in Japan (Imajima, 1996).

This is the first record from off Shirahama.

Family Glyceridae Grube, 1850

Genus Glycera Lamarck, 1818

6. Glycera onomichiensis Izuka, 1912 [Jn: Onomichi-chirori]

Materials examined. SMR15-04-1 (2)

Family Aphroditidae Malmgren, 1867

Genus Laetmonice Kinberg, 1856

7. Laetmonice japonica McIntosh, 1885 [Jn: Nihon-urokomushi]

Materials examined. SMR15-04-3 (1)

Family Polynoidae Kinberg, 1856

Genus Lepidasthenia Malmgren, 1867

8. Lepidasthenia $\mathrm{sp.}$

Materials examined. SMR15-04-1 (1)

9. Polynoidae gen. sp.

Materials examined. SMR15-04-1 (10), SMR15-04-3 (1)

Family Pilargidae de Saint-Joseph, 1899

Genus Sigambra Müller, 1858

10. Sigambra hanaokai (Kitamori, 1960) [Jn: Hanaoka-kagigokai]

Materials examined. SMR15-04-4 (1)

Family Amphinomidae Lamarck, 1818

Genus Chloeia Lamarck, 1818

11. Chloeia sp.

Materials examined. SMR15-04-1 (4)

Family Euphrosinidae Williams, 1852

12. Euphrosinidae gen. sp.

Materials examined. SMR15-04-1 (1) 


\section{MASANORI OKANISHI ET AL.}

Family Eunicidae Berthold, 1827

13. Eunicidae gen. sp.

Materials examined. SMR15-04-1 (11)

Family Lumbrineridae Schmarda, 1861

Genus Scoletoma Blainville, 1828

14. Scoletoma sp.

Materials examined. SMR15-04-3 (1)

15. Lumbrineridae gen. sp.

Materials examined. SMR15-04-3 (6)

Family Onuphidae Kinberg, 1865

Genus Hyalinoecia Malmgren, 1867

16. Hyalinoecia tubicola (O.F. Müller, 1776) [Jn: Tuno-Isome]

Materials examined. SMR15-04-2 (1)

17. Onuphidae gen. sp.

Materials examined. SMR15-04-1 (10)

Family Chaetopteridae Audouin and Milne Edwards, 1833

Genus Spiochaetopterus M Sars, 1856

18. Spiochaetopterus sp.

Materials examined. SMR15-04-1 (16)

19. Chaetopteridae gen. spp.

Materials examined. SMR15-04-2 (3), SMR15-04-3 (10).

Family Magelonidae Cunningham and Ramage, 1888

Genus Magelona F. Müller, 1858

20. Magelona japonica Okuda, 1937 [Jn: Morote-Gokai]

Materials examined. SMR15-04-4 (1)

Family Poecilochaetidae Hannerz, 1956

Genus Poecilochaetus Claparède in Ehlers, 1875

21. Poecilochaetus elongatus Imajima, 1989 [Jn: Kazari-Tokkuri-Gokai]

Materials examined. SMR15-04-4 (2)

22. Poecilochaetus sp.

Materials examined. SMR15-04-4 (2) 


\section{BENTHIC FAUNA OF SHIRAHAMA}

Family Ampharetidae Malmgren, 1866

Genus Samythella Verrill, 1873

23. Samythella sp.

Materials examined. SMR15-04-1 (1)

Remarks. Samythella bathycola and S. neglecta have been recorded from Japan (Imajima, 2015).

This species is distinguished from the two known species by tentacle shape and number of abdominal setiger and is potentially undescribed.

Family Terebellidae Johnston, 1846

Genus Polycirrus Grube, 1850

24. Polycirrus sp.

Materials examined. SMR15-05-2 (1)

25. Terebellidae gen. sp.

Materials examined. SMR15-04-1 (2), SMR15-04-4 (1).

Family Trichobranchidae Malmgren, 1866

Genus Terebellides Sars, 1835

26. Terebellides kobei Hessle, 1917 [Jn: Nise-Tamagushi-Fusa-Gokai]

Materials examined. SMR15-04-4 (13).

Family Pectinariidae Quatrefages, 1866

Genus Lagis Malmgren, 1866

27. Lagis sp.

Materials examined. SMR15-04-1 (1)

Family Cirratulidae Carus, 1863

Genus Cirratulus Lamarck, 1818

28. Cirratulus sp.

Materials examined. SMR15-04-2 (1)

Genus Chaetozone Malmgren, 1867

29. Chaetozone sp.

Materials examined. SMR15-05-2 (7)

Family Flabelligeridae de Saint-Joseph, 1894

Genus Diplocirrus Haase, 1915

30. Diplocirrus nicolaji (Buzhinskaja, 1994) (Fig. 5B) [Jn: Bouzu-Habouki]

Materials examined. SMR15-05-2 (2*)

Remarks. This species has been recorded from Oshoro, Tateyama, Misaki, Hiroshima (Jimi et al. 2016). This is the first record from off Shirahama and the southernmost record of the species. 


\section{MASANORI OKANISHI ET AL.}

Family Sternaspidae Carus, 1863

Genus Sternaspis Otto, 1821

31. Sternaspis affinis Stimpson, 1864

Materials examined. SMR15-04-4 (2)

Family Maldanidae Malmgren, 1867

Genus Nicomache Malmgren, 1865

32. Nicomache sp.

Materials examined. SMR15-04-1 (1)

Family Opheliidae Malmgren, 1867

Genus Armandia Filippi, 1861

33. Armandia amakusaensis Saito, Tamaki and Imajima, 2000 [Jn: Tutuo-Ophelia]

Materials examined. SMR15-05-2 (1)

Family Capitellidae Grube, 1862

34. Capitellidae gen. sp.

Materials examined. SMR15-05-2 (1)

Family Oweniidae Rioja, 1917

Genus Owenia Delle Chiaje, 1844

35. Owenia sp.

Materials examined. SMR15-04-1 (2), SMR15-04-2 (1).

Remarks. Owenia gomsoni and O. fusiformis have been recorded from Japan (Imajima 2001, Nishi et al., 2004). This species is distinguished from the two known species by prostomium color in life, and is potentially undescribed.

Genus Myriochele Malmgren, 1867

36. Myriochele heeri Malmgren, 1867 [Jn: Bouzu-Chimakigokai]

Materials examined. SMR15-04-2 (2)

37. Myriochele sp. (Fig. 5C)

Materials examined. SMR15-04-3 (1)

Remarks. This species is distinguished from the related species of Myriochele by prostomium shape and color band pattern, and is potentially undescribed.

Genus Galathowenia Kirkegaard, 1959

38. Galathowenia oculata (Zachs, 1923) (Fig. 5D) [Jn: Manako-Chimakigokai]

Materials examined. SMR15-04-3 (1)

Family Sabellariidae Johnston, 1865

Genus Lygdamis Kinberg, 1867 


\section{BENTHIC FAUNA OF SHIRAHAMA}

39. Lygdamis japonicus Nishi and Kirtley, 1999 [Jn: Hana-Kanmurigokai]

Materials examined. SMR15-04-1 (1)

Family Sabellidae Latreille, 1825

Genus Laonome Malmgren, 1866

40. Laonome sp.

Materials examined. SMR15-04-1 (2)

41. Sabellidae gen. sp.

Materials examined. SMR15-05-2 (1)

\section{General remarks}

\section{Phylum Tardigrada}

We collected at least three species from three genera, one family of the order Arthrotardigrada (class Heterotardigrada) including an undescribed species and a potentially undescribed species. An expansion of habitat range is recorded for Angursa clavifera. The sorting and identification of specimens are still in progress.

Class Heterotardigrada Marcus, 1927

Order Arthrotardigrada Marcus, 1927

Family Halechiniscidae Thulin, 1928

Subfamily Styraconyxinae Kristensen and Renaud-Mornant, 1983

Genus Angursa Pollock, 1979

1. Angursa clavifera Noda, 1985 (Fig. 6A)

Material examined. SMR15-03-1 $(1 *)$

Remarks. A four claw juvenile was collected. It is identified to this species based on the following combination of characters: club shaped primary clavae, presence of secondary and tertiary clavae (the exact outlines of these characters were not observable), leg IV sensory organs as enveloped, spherical papillae and short peduncles. However, the sensory organs of legs II and III were not recognized probably due to the leg orientation. This species has been only known from the beach environment (Noda 1985; 1994) and this is the first record of this species from the sublittoral zone.

Genus Raiarctus Renaud-Mornant, 1981

2. Raiarctus sp. (Fig. 6B)

Material examined. SMR15-03-1 (1), SMR15-04-1 (1*)

Remarks. An adult female and a four claw juvenile were collected. This species resembles Raiarctus aureolatus and $R$. katrinae by the alae-like structure surrounding the body with relatively long pillars. However, it differs from the two known species by the morphology of the cephalic cirri and the leg IV sensory organ. The description of this species is in process.

Family Tanarctinae Renaud-Mornant, 1980

Genus Tanarctus Renaud-Debyser, 1959 


\section{MASANORI OKANISHI ET AL.}

3. Tanarctus sp. (Fig. 6C)

Material examined. SMR15-04-1 (1*)

Remarks. A two claw juvenile was collected. This species is characterized by the presence of the club-shaped secondary clavae and the simple leg IV appendages. It differs from $T$. diplocerus, a species reported from a shallower site (water depth: $8.4 \mathrm{~m}$ ) in the same region (Fujimoto et al. 2013), by the former character. For further identification, collection of four claw juveniles and adult specimens are necessary.

\section{Phylum Arthropoda}

Subphylum Crustacea Brünnich, 1772

Class Copepoda Milne-Edwards, 1840

Order Siphonostomatoida Thorell, 1859

Pennellidae Burmeister, 1835

Genus Cardiodectes Wilson C.B., 1917

\section{Cardiodectes sp. (Fig. 6D-F)}

Material examined. SMR 15-04-3 (3*2) (Fig. 6D), SMR 16-01-1 (2*) (Fig. 6E, F)

Remarks. All individuals were parasitic on eyes of Pteropsaron evolans (SMR 15-04-3) and Osopsaron formosense (SMR 16-01-1). The copepod is a member of Cardiodectes based on the key to genera of Pennellidae by Uyeno (2015). It is potentially undescribed because of combination of some morphological characters and its description is in process.

\section{Phylum Echinodermata}

Class Echinoidea Leske, 1778

\section{General remarks}

We collected five species from three genera, two families including a potentially undescribed species and a new record from off Shirahama. Systematics follows Kroh and Smith (2010) and Japanese names follow Shigei (1986).

Order Camarodonta, Jackson, 1912

Family Temnopleuridae A. Agassiz, 1872

Genus Temnopleurus L. Agassiz, 1841

1. Temnopleurus apodus (A. Agassiz and H. L. Clark, 1906) (Fig. 7A, B) [Jn: Shirotsubu-Sansyo-Uni] Material examined. SMR15-04-2 (1*)

2. Temnopleuridae gen. sp. (Fig. 7C, D)

Material examined. SMR15-04-2 (2*)

Remarks. Two juveniles with undeveloped taxonomic characters were collected. This species is distinguished from $T$. apodus by having two buccal podia in each five pairs of buccal plates. Sampling of adults is necessary for further identification to the genus or species-level.

Order Clypeasteroida L.Agassiz, 1835

Infraorder Laganiformes Desor, 1847

Family Fibulariidae Gray, 1855

Genus Echinocyamus van Phelsum, 1774 


\section{BENTHIC FAUNA OF SHIRAHAMA}

3. Echinocyamus provectus de Meijere, 1903 (Fig. 7E, F)

Material examined. SMR15-04-2 (2*)

Remarks. The two collected specimens were dead denuded tests. Therefore, it cannot be decided whether Echinocyamus provectus lives on the sampling site or not (southwest off Shirahama, approximately $125 \mathrm{~m}$ depth).

4. Echinocyamus subconicus Mortensen, 1948 (Fig. 7G, H)

Material examined. SMR15-04-2 (6*)

Remarks. This species has been reported only once from southwest of Nagasaki, western Japan (Shigei, 1981). This is the first record from off Shirahama and the expansion of northernmost distribution record.

Genus Fibularia Lamarck, 1816

\section{Fibularia sp. (Fig. 7I, J)}

Material examined. SMR15-06-2 (1*)

Remarks. This species is distinguished from its congeners by flattened test and developed each petal. Description of this undescribed species is in process.

\section{Class Holothuroidea de Blainville, 1834}

\section{General remarks}

We collected thirteen species from ten or more genera, four or more families including one potentially undescribed species. Systematics follows Imaoka (1995), Rowe and Gates (1995), and Ohshima (1915-1918), and Japanese names follow Imaoka (1995) and Utinomi (1965).

Order Apodida Brandt, 1835

Family Synaptidae Burmeister, 1837

Genus Labidoplax Östergren, 1898

1. Labidoplax variabilis (Theel, 1886) (Fig. 8A)

Material examined. SMR 15-04-4 (3), SMR 15-05-3 (1), SMR 15-06-1 (1*)

Genus Leptosynapta Verril, 1867

2. Leptosynapta sp. (Fig. 8B)

Material examined. SMR 15-05-3 (2), SMR 15-06-2 (1*)

Remarks. This species has been known as Leptosynapta inhaerens (Müller, 1776) [Jn:

Hoso-Ikari-Namako]. However, recent morphological studies (Massin et al., 2014) indicate that this species can be distinguished from $L$. inhaerens in lacking grain-ossicles of longitudinal muscles.

Order Dendrochirotida Grube, 1840

Family unknown 


\section{MASANORI OKANISHI ET AL.}

3. Unknown species 1 (Fig. 8C)

Material examined. SMR 15-04-1 (1*)

Remarks. This specimen has very unique unsymmetrical shaped ossicle in the body wall, well matured gonad, and has thick color. However, loss of tentacles and the calcareous ring prevent it from further identification.

4. Unknown species 2 (Fig. 8D)

Material examined. SMR 15-04-1 (1*)

Remarks. This specimen has gonad, however, loss of tentacles and the calcareous ring prevent it from further identification. The symmetrical shaped body wall ossicles and white or thin body color of this species is different from Unknown species 1.

Family Cucumariidae Ludwig, 1894

Genus Amphicyclus Bell, 1884

5. Amphicyclus sp.? (Fig. 8E)

Material examined. SMR 15-04-1 (1*)

Remarks. An incomplete calcareous ring infer its immature development, and it prevent the specimen from identification to species.

Genus Neocucumis Deichmann, 1944

6. Neocucumis sp.? 1 (Fig. 8F)

Material examined. SMR 15-04-1 (1*)

Remarks. This species is similar to Neocucumis sagamiensis (Ohshima, 1915), however, there are slight differences in the morphological layout and shape of pedicels. In this specimen, the pedicels are scattered on whole the body surface, while Ohshima (1915) reported that the pedicels were arranged in two rows along each ambulacrum in $N$. sagamiensis.

7. Neocucumis sp.? 2 (Fig. 8G)

Material examined. SMR 15-04-2 (1*)

Remarks. This specimen is distinguished from Neocucumis sp.? 1 in having the pedicels arranged in two rows along each ambulacrum. However, its incomplete calcareous ring, which may be a evidence of its immaturity, prevent it from identification to species.

Genus Pentacta Goldfuss, 1820

8. Pentacta? sp. (Fig. $8 \mathrm{H})$

Material examined. SMR 15-04-1 (1*)

Remarks. This specimen has characteristics of the genus Pentacta or Plesiocolochirus, however, taxonomic states of the two genera are presently uncertain.

Genus Pseudocnus Panning, 1949

9. Pseudocnus sp.? (Fig. 8I)

Material examined. SMR 13-04-2 (2), SMR 15-04-1 (3), SMR 15-04-2 (1*), SMR 15-07-1 (1)

Remarks. This species belongs to subfamily Cucumariinae. However, the taxonomic state of the subfamily is presently uncertain. 


\section{BENTHIC FAUNA OF SHIRAHAMA}

Family Phyllophoridae Östergren, 1907

Genus Neothyonidium Deichmann, 1938

10. Neothyonidium sp. (Fig. 8J)

Material examined. SMR 15-07-1 (1*)

Remarks. This specimen is in states of immature development, and it prevent the specimen from identification to species.

Genus Pentamera Ayres, 1852

\section{Pentamera sp. (Fig. 8K)}

Material examined. SMR 15-04-3 (3*)

Remarks. One of the specimens has a well matured gonad. In the body wall, all the specimens possess thick table ossicles with irregular shaped disc and with or without a short two pillared spire. No other congeners have those characters and this species is considered potentially undescribed species. It was also obtained in Misaki, Kanagawa, eastern Japan (unpubl. data).

Genus Stolus Selenka, 1867

12. Stolus punctata (Ohshima, 1915) (Fig. 8L)

Material examined. SMR 15-04-3 (1*)

Family Psolidae Burmeister, 1837

Genus Psolus Oken, 1815

13. Psolus sp. (Fig. 8M)

Material examined. SMR 15-04-1 (2*)

Remarks. Incomplete calcareous rings inferred its immature development and it prevent the two specimens from identification to species.

Class Ophiuroidea Gray, 1840

\section{General remarks}

We collected 27 species from 17 genera, eleven families, including one potentially undescribed species, 16 new records from Shirahama and two new records from Japan. Two specimens of potentially undescribed species may be a juvenile and an adult. To clarify the species' taxonomic status, additional specimens covering other developmental stages and molecular information are required. Systematics follows Stöhr et al. (2012) and Japanese names follow Irimura (1995) and Fujita et al. (2015).

Order Euryalida Lamarck, 1816

Family Euryalidae Gray, 1840

Genus Astroceras Lyman, 1879

\section{Astroceras coniunctum Murakami, 1944 [Jn: Oni-Tsuno-mozuru]}

Material examined. SMR15-04- 1 (1)

Remarks. This species has been recorded from Ogasawara Islands (Murakami, 1944), Tosa Bay, Kumano Sea and Okinawa (Okanishi et al., 2014). This is the first record from off Shirahama. 


\section{MASANORI OKANISHI ET AL.}

Order Ophiurida Müller and Troschel, 1842

Family Amphiuridae Ljungman, 1867

Genus Amphioplus Verrill, 1899

2. Amphioplus (Amphichilus) trichoides Matsumoto, 1917 (Fig. 9A)

Material examined. SMR15-04-4 (3), SMR15-06-1 (1*)

Remarks. This species has been recorded from Sagami Sea (Matsumoto, 1917), off Ishikawa

(Murakami, 1943), off Amakusa (Irimura, 1969), off Kumano (Saba et al., 1982) and south Korea

(Ishida et al., 2001). This is the first record from off Shirahama.

3. Amphioplus (Amphioplus) ancistrotus? (Fig. 9B)

Material examined. SMR15-01-2 (2*)

Genus Amphipholis Ljungman, 1866

4. Amphipholis squamata (Delle Chiaje, 1828) (Fig. 9C) [Jn: Iso-Komochi-Kumohitode]

Material examined. SMR13-03-2 (1), SMR15-02-2 (2*), SMR15-04-1 (2)

Genus Amphiura Forbes, 1843

5. Amphiura (Ophiopeltis) aestuarii Matsumoto, 1915 (Fig. 9D) [Jn: Megane-Kumohitode]

Material examined. SMR13-03-3 (2), SMR13-03-4 (1), SMR15-05-4 (1*), SMR15-06-1 (1)

Remarks. This species has been recorded from Sagami Sea (Matsumoto, 1917), off Ishikawa

(Murakami, 1943), off Amakusa (Irimura, 1969) and off Kumano (Saba et al., 1982). This is the first record from off Shirahama.

6. Amphiura (Amphiura) koreae Duncan, 1879 (Fig. 9E) [Jn: Cho-Sen-Kumohitode]

Material examined. SMR15-02-2 (1*)

Remarks. This species has been recorded from Sagami Sea, Kagoshima Gulf and Sea of Japan

(Mataumoto, 1917), Suruga Bay (Matsumoto, 1917; Irimura, 1991; Fujita et al., 1997), off Sanriku

(Irimura, 1991), Sendai Bay (Fujita, 1996) and off Noto (Fujita and Kohtsuka, 2003). This is the first record from off Shirahama.

7. Amphiura (Amphiura) micraspis (Fig. 9F) H.L.Clark, 1911

Material examined. SMR13-03-4 (1*), SMR13-04-2 (1).

Remarks. This species has been recorded from off Omai-Zaki (Matsumoto, 1917), off Amakusa

(Irimura, 1969), Suruga Bay (Fujita et al., 1997), off Oki Island (Fujita et al., 2004). This is the first record from off Shirahama.

8. Amphiura (Fellaria) vadicola (Fig. 9G) Matsumoto, 1915

Materials examined. SMR13-03-5 (4*)

Genus Ophiophragmus Lyman, 1865

9. Ophiophragmus japonicas Matsumoto, 1915

Materials examined. SMR13-02-3 (1), SMR15-04-3 (1)

Remarks. This species ha been recorded from Kagoshima Bay, Suruga Bay and Rikuzen (Matsumoto, 1917). This is the first record from off Shirahama. 


\section{BENTHIC FAUNA OF SHIRAHAMA}

Family Ophiacanthidae Ljungman, 1867

Genus Ophiomitrella Verrill, 1899

10. Ophiomitrella stellifera Matsumoto, 1917 (Fig. 9H)

Material examined. SMR15-02-2 (1*)

Remarks. This species has been recorded from off Izu (Matsumoto, 1917) and Sagami Sea (Irimura, 1982; Fujita et al., 2006). This is the first record from off Shirahama.

Genus Ophiomyces Lyman, 1869

11. Ophiomyces papillospinus Litvinova, 2001 [New Jn: Toge-Kanmuri-Kumohitode]

Material examined. SMR13-02-1 (2*), SMR15-01-1 (1), SMR15-04-3 (4)

Remarks. Ophiomyces papillospinus is known from $510 \mathrm{~m}$ of south off New Caledonia so far (Litvinova, 2001) and this is the first record of this species from Japanese water, with the shallowest record at $75 \mathrm{~m}$. New Japanese name "Toge-Kanmuri-Kumohitode" is proposed for this species.

Family Ophiactidae Matsumoto, 1915

Genus Ophiactis Lütken, 1856

12. Ophiactis dyscrita H.L. Clark, 1911 (Fig. 9I) [New Jn: Noumen-Kumohitode]

Material examined. SMR15-04-1 (1*), SMR15-04-2 (1)

Remarks. This species has been recorded from Sagami Sea (Matsumoto, 1917), off Amakusa

(Irimura, 1969), South Korea (Ishida et al., 2001) and off Ogasawara Islands (Irimura and

Tachikawa, 2003). This is the first record from off Shirahama. New Japanese name

"Noumen-Kumohitode" is proposed for this species.

13. Ophiactis macrolepidota Marktanner-Turneretscher, 1887 (Fig. 9J) [Jn: Dairin-Chibi-Kumohitode]

Material examined. SMR13-01-1 (4*), SMR15-04-2 (1)

14. Ophiactis profundi Lütken and Mortensen, 1899 (Fig. 9K) [Jn: Ara-Uroko-Kumohitode]

Material examined. SMR15-02-2 (2*)

Family Ophiodermatidae Ljungman, 1867

Genus Ophiopsammus Lütken, 1869

15. Ophiopsammus anchista (H.L.Clark, 1911) (Fig. 9L) [Jn: Menashi-Kumohitode]

Material examined. SMR13-01-2 (1*)

Remarks. The examined individual show striking orange color bands on arms and concentric patterns on their aboral body on white back ground color. This probably is the first recorded color pattern for this species.

Genus Ophiurochaeta Matsumoto, 1915

16. Ophiurochaeta mixta (Lyman, 1878) (Fig. 9M)

Material examined. SMR14-03-4 (2*)

Remarks. This is the first record of this genus from Japanese waters. 


\section{MASANORI OKANISHI ET AL.}

Family Ophiolepididae Ljungman, 1867

Genus Ophiomusium Lyman, 1869

17. Ophiomusium lymani Wyville-Thomson, 1873 [Jn: Lyman-Kumohitode]

Material examined. SMR15-02-2 (5*), SMR15-04-1 (2), SMR15-04-2 (1)

Remarks. This species has been recorded from off Omai-Zaki and Sea of Japan (Matsumoro, 1917)

and Tosa Bay (Irimura, 1991). This is the first record from off Shirahama.

18. Ophiomusium scalare Lyman, 1878 [Jn: Taira-Ishigaki-Kumohitode]

Material examined. SMR13-01-2 (4*)

Family Ophioleucidae Matsumoto, 1915

Genus Ophioleuce Koehler, 1904

19. Ophioleuce seminudum Koehler, 1904 (Fig. 9N) [Jn: Goyou-Kumohitode]

Material examined. SMR15-07-1 (2*)

Remarks. This species has been recorded from Sagami Sea (Matsumoro, 1917, Irimura, 1982),

Suruga Bay (Fujita et al., 1997) off Shimoda (Irimura et al., 2001), East China Sea (Fujita and Irimura, 2005) and Sea of Japan (Matsumoto, 1917; Fujita et al., 2014). This is the first record from off Shirahama.

Family Ophiomyxidae Ljungman, 1867

20. Ophiodera? sp. (Fig. 9O, P)

Material examined. SMR13-01-2 (1*)

Remarks. This species may belong to Ophiomyxidae in the features of having skin covering disc and lacks of dorsal arm plates. The most striking feature of this species is their fan-shaped upper-most arm spines and they have never seen in other Ophiodera species. Description of this undescribed species is in process.

Genus Ophiologimus H.L. Clark, 1911

21. Ophiologimus hexactis H.L.Clark, 1911 (Fig. 9Q) [Jn: Mutsuude-Kawa-Kumohitode]

Material examined. SMR13-01-2 (7*), SMR15-02-2 (2), SMR15-04-1 (1)

Remarks. This species has been recorded from Sagami Sea (Matsumoto, 1917; Fujita et al., 2006) and Suruga Bay (Fujita et al., 1997). This is the first record from off Shirahama.

Family Ophionereididae Ljungman, 1867

Genus Ophiocrasis H.L. Clark, 1911

22. Ophiocrasis dictydisca H.L. Clark, 1911 (Fig. 9R)

Material examined. SMR14-01-1 (3*)

Remarks. This species has been recorded from Sagami Bay (Matsumoto, 1917). This is the first record from off Shirahama.

Family Ophiotrichidae Ljungman, 1867

Genus Ophiothrix Müller and Troschel, 1842 
23. Ophiothrix koreana Duncan, 1879 (Fig. 9S)

Material examined. SMR15-02-2 (2*), SMR15-04-1 (5)

24. Ophiothrix panchyendyta H.L. Clark, 1911 (Fig. 9T) [Jn: Toge-Kumohtiode]

Mateirial examined. SMR13-01-1 (1*)

Remarks. This species has been recorded from Korea Strait (Matsumoto, 1917), Sagami Sea (Irimura, 1982), off Tsushima (Irimura, 1990), Sendai Bay (Fujita, 1996), Suruga Bay (Fujita et al., 1997) and East China Sea (Irimura and Kubodera, 1998; Fujita and Irimura, 2005). It is surprisingly that this common species has never been recorded from off Shirahama.

Family Ophiuridae Lyman, 1865

Genus Ophiura Lamarck, 1801

25. Ophiura kinbergi Ljungman, 1866 (Fig. 9U) [Jn: Kushinoha-Kumohitode]

Material examined. SMR13-01-1 (24*), SMR13-03-1 (1), SMR15-01-2 (2), SMR15-03-2 (1), SMR15-04-2 (3), SMR15-04-3 (6), SMR15-07-2 (316), SMR15-07-4 (96)

26. Ophiura ooplax (H.L. Clark, 1911) (Fig. 9V) [Jn: Hana-Kushinoha-Kumohitode]

Material examined. SMR15-04-2 (1*)

Remarks. This species has been recorded from Sagami Sea and Sea of Japan (Matsumoto, 1917), off Kumano (Saba et al., 1982) Suruga Bay (Fujita et al., 1997). This is the first record from off Shirahama.

27. Stegophiura vivipara [Jn: Komochi-Kumohitode] (Fig. 9W)

Material examined. SMR13-01-1 (5*), SMR13-02-2 (11), SMR15-01-2 (2), SMR15-04-1 (7)

Remarks. This species has been recorded from Sagami Sea (Matsumoto, 1917; Irimura, 1982),

Suruga Bay (Fujita et al., 1997) off Shimoda (Irimura et al., 2001), off Ogasawara Islands (Irimura and Tachikawa, 2003), off Oki Island (Fujita et al., 2004) and East China Sea (Fujita and Irimura, 2005). This is the first record from off Shirahama.

\title{
Phylum Chordata
}

\section{General remarks}

We collected ten species from ten genera, eight families, including two new records from off Shirahama. Systematics follow Nakabo and Nakayama (2013).

\author{
Class Osteichthyes \\ Order Gadiformes \\ Family Bregmacerotidae Gill, 1872 \\ Genus Bregmaceros Thompson, 1840
}

1. Bregmaceros nectabanus Whitley, 1941 (Fig. 10A) [Jn: Toyama-Sai-Uo]

Material examined. SMR15-04-4 (1*)

Remarks. Bregmaceros nectabanus is commonly known from Japanese waters (Nakabo and Kai, 2013), but this is the first record of off Shirahama. 


\section{MASANORI OKANISHI ET AL.}

Order Perciformes

Family Callionymidae Bonaparte, 1831

Genus Repomucenus Whitley, 1931

2. Repomucenus virgis (Jordan and Fowler, 1903) (Fig. 10B) [Jn: Horo-Numeri]

Material examined. SMR13-01-1 (1), SMR15-07-2 (1*)

Family Champsodontidae Jordan and Snyder, 1902

Genus Champsodon Günther, 1867

3. Champsodon snyderi Franz, 1910 (Fig. 10C) [Jn: Wani-Gisu]

Material examined. SMR15-07-2 (1*)

Family Gobidae Cuvier, 1816

Genus Paratrypauchen Murdy, 2008

4. Paratrypauchen microcephalus (Bleeker, 1860) (Fig. 10D) [Jn: Akauo]

Material examined. SMR15-04-4 (1*)

Family Percophidae Swainson, 1839

Genus Pteropsaron Jordan and Snyder, 1902

5. Pteropsaron evolans Jordan and Snyder, 1902 [Jn: Hokake-Tora-Gisu]

Material examined. SMR15-04-3 (1)

Family Pinguipedidae Günther, 1860

Genus Parapercis Bleeker, 1863

6. Parapercis sp. Bleeker, 1863 (Fig. 10E)

Material examined. SMR15-07-1 (1*)

Remarks. The present specimen cannot be identified because of lacking a body part.

Family Serranidae Swainson, 1839

Genus Plectranthias Bleeker, 1873

7. Plectranthias kelloggi azumanus (Jordan and Richardson, 1910) (Fig. 8F) [Jn: Azuma-Hana-Dai] Material examined. SMR15-04-1 (1*)

Order Pleuronectiformes

Family Cynoglossidae Jordan, 1888

Genus Symphurus Rafinesque, 1810

8. Symphurus orientalis (Bleeker, 1879) (Fig. 10G) [Jn: Azuma-Garei]

Material examined. SMR15-04-2 (1*)

Remarks. Symphurus orientalis is known from Heda, Owase, Tosa Bay, Shibushi Bay and East

China Sea (Yamada and Yagishita, 2013). This is the first record from off Shirahama. 


\title{
BENTHIC FAUNA OF SHIRAHAMA
}

Family Paralichthyidae Regan, 1910

Genus Pseudorhombus Bleeker, 1862

\section{Pseudorhombus pentophthalmus Günther, 1862 (Fig. 10H) [Jn: Tama-Ganzo-Birame] Material examined. SMR15-07-2 (1*), SMR15-07-4 (1)}

Genus Tarphops Jordan and Thompson, 1914

\author{
10. Tarphops elegans Amaoka, 1969 (Figure 10(I)) [Jn: Yume-Arame-Garei] \\ Material examined. SMR15-04-3 (1*)
}

\section{Discussion}

Although animals examined in this study were only a small fraction of SMR samples, we obtained 132 species from seven phyla in total with six undescribed species and five potentially undescribed species, 22 new record species from off Shirahama and two new records from Japan (Table 2). A summary of remarkable discoveries are as follows.

Six undescribed species were found in four invertebrate phyla (Mollusca: Cylindriscala sp. and Gymnodoris sp., Tardigrada: Raiarctus sp., Arthropoda: Cardiodectes sp., and Echinodermata: Fibularia sp. and Ophiodera? sp.), and five potentially undescribed species were found in three phyla (Annelida: Samythella sp. Owenia sp. Myriochele sp., Tardigrada: Tanarcus sp., and Echinodermata: Pentamera sp.) (Table. 2). These species are in process of description or further identification under each expert. For tardigrades, the three species found in this study are the deepest records from Japanese waters. We collected one new record of a fish species (Symphurus pentophthalmus) from Shirahama. This finding is a surprise because the fish fauna in Japan is relatively well studied (e.g. Nakabo, 2013). We refrain from comparing benthos communities with respect to each depth zone (shallower, intermediate and deeper) because all samples were not identified in this study. But it is noteworthy that the 'intermediate depth zone (approximately 40-100 m)', included an undescribed species, Cardiodectes sp. (Arthropoda, Crustacea, Copepoda) and two potentially undescribed species, Myriochele sp.(Annelida, Oweniidae) and Pentamera sp.(Holothroidea, Dendrochirotida), and 6 newly recorded species in Ophiuroidea. Annelida and Holothuroidea have also been well studied in Shirahama (e.g. Fauvel, 1936; Imaoka, 1995; Imajima, 1996, 2001, 2007, 2015) and it shows that the 'intermediate depth zone' is an overlooked and unexplored environment in ocean.

According to the strict definition, the parasitic copepod (Cardiodectes sp.) is not a benthos. Accomplishment of this unexpected finding by the present sampling method should be noted here. Moreover, a living specimen of undescribed species of sand-burrowing echinoids (Fibularia sp.) was found in shallow waters near Hatakejima Island $(5 \mathrm{~m}$ ) (Table 2). In this Kyoto University possessed island, at intertidal zone, successive inventory researches of marine biodiversity have been conducted for more than 50 years. Finding of this small irregular echinoid species implicates that sand-borrowers may remain undiscovered even in littoral zone of one of the most intensively studied marine areas in the world (Table 2). Surveys focused on those 'overlooked' depth and environment would be desired for future marine biodiversity surveys around Shirahama.

Sponges, decapods, bryozoans and kinorhynchs and other benthic invertebrates were collected during the SMR but are not reported herein. Further examinations for the remaining samples would provide more taxonomic findings.

Images of living specimens provided several significant insights. For example, the ophiurid Ophiopsammus anchista showed beautiful vivid orange stripes on its body, a color pattern which has not been 


\section{MASANORI OKANISHI ET AL.}

previously reported (Fig. 7L). In total, photographs of 88 out of 132 species were provided in this study. Combination of these photographs, accurate sampling locality information and species list provide a graphic record of the biodiversity of the fauna from this region for future records.

On the other hand, we could not reconcile species which had only once originally described from the present study area. For example, Ophiolepis utinomii and Ophiocentrus tokiokai (Ophiuroidea) was originally described from subtidal zone of Hatakejima Island (Irimura, 1981) but not discovered during this study. The successive investigations must be important to encourage further monitoring of biotic transition, which should directly connect to environmental changes and we should be able to discuss the extinction of these species by those investigations.

We here conclude that our successive and detailed surveys covering wide range of depth and taxa accompanied with accurate locality data, and species-level identifications, provide important and fundamental information for future marine biodiversity research.

\section{Acknowledgements}

We wish to express our sincere gratitude to Dr. Christopher L. Mah of the National Museum of Natural History, Washington, D.C. for his reading of the manuscript and constructive comments. We here express our thanks to all the researchers and students that participated in the Shirahama Marine Research and also the researchers who helped in species identification of Annelida, Masanori Sato of Kagoshima University (Nereis or Neanthes sp.) and Ryo Mukai of Miyazaki University (Sternaspis affinis). We also thank all the staffs of SMBL for their support during the survey. SF was supported by Japan Society for the Promotion of Science Grant-in-Aid for JSPS fellows (Grant No. 25987).

\section{Literature cited}

Akiyama, T., Shimomura, M. and Nakamura, K. 2008. Collection of deep-sea small arthropods: gears for collection and processing of samples on deck. TAXA, 24, 27-32. (In Japanese)

Amante, C. and Eakins, B. W. 2009. ETOPO1 1 Arc-Minute Global Relief Model: Procedures, data sources and analysis. NOAA Technical Memorandum NESDIS NGDC-24. National Geophysical Data Center, NOAA, doi:10.7289/V5C8276M [access date 23.04.15].

Bieri, R. and Tokioka, T. 1968. Dragonet II, an opening-closing quantitative trawl for the study of microvertical distribution of zooplankton and the meio-benthos. Publications of the Seto Marine Biological Laboratory, 15 (5), 373-390.

Bouchet, P. and Rocroi, J. P. 2005. Classification and nomenclature of gastropod families. Malacologia, 47 (1-2), 1-397.

Bouchet, P., Rocroi, J. P., Bieler, R., Carter, J. G. and Coan, E. V. 2010. Nomenclature of bivalve families with a classification of bivalve families. Malacologia, 52 (2), 1-184.

Burgess, R. 2001. An improved protocol for separating meiofauna from sediments using colloidal silica sols. Marine Ecology Progress Series, 214, 161-165.

Fauvel, P. 1936. Annélides polychètes du Japon. Memoirs of the College of Science, Kyoto Imperial University, Series B, 12 (1), 41-92.

Fujikura, K., Lindsay, D., Kitazato, H., Nishida, S. and Shirayama, Y. 2010. Marine biodiversity in Japanese waters. PLoS ONE, 5 (8), e11836. doi:10.1371/journal.pone.0011836.

Fujimoto, S., Miyazaki, K. and Suzuki, A. C. 2013. A new marine tardigrade, Tanarctus diplocerus (Arthrotardigrada: Halechiniscidae) from Japan. Journal of the Marine Biological Association of the United Kingdom, 93 (4), 955-961. 
Fujimoto, S. 2015. Quisarctus yasumurai gen. et sp. nov. (Arthrotardigrada: Halechiniscidae) from a submarine cave, off Iejima, Ryukyu Islands, Japan. Zootaxa, 3948 (1), 145-150.

Fujita, T. 1996. Bathymetric distribution of ophiuroids (Echinodermata) off Sendai Bay, northern Japan, with notes on the diet of the Roughscale Sole Clidoderma asperrimum (Pisces, Pleuronectidae). Memoirs of the National Museum of Nature and Science, 29, 209-222.

Fujita, T., Ishida, Y. and Irimura, S. 1997. Ophiuroids collected from the deep waters of Suruga Bay, Central Japan. National Science Museum Monographs, 12, 257-268.

Fujita, T. and Kohtsuka, H. 2003. Ophiuroids (Echinodermata) from Notojima Island and its adjacent waters in the Sea of Japan. Report of the Noto Marine Center, 9, 25-38.

Fujita, T., Ishida, Y., Kato, T. and Irimura, S. 2004. Ophiuroids (Echinodermata) collected from the Oki Islands in the Sea of Japan. Bulletin of the National Science Museum Series A (Zoology), 30 (4), 191218.

Fujita, T. and Irimura, S. 2005. Ophiuroids (Echinodermata) collected by R/V Yoko-Maru off southwestern Japan in the East China Sea. National Science Museum Monographs, 29, 357-384.

Fujita, T., Ishida, Y. and Irimura, S. 2006. Preliminary report of Ophiacanthidae (Echinodermata, Ophiuroidea) collected from the Sagami Sea, central Japan. Memoirs of the National Museum of Nature and Science, 41, 289-303.

Fujita, T., Ishida, Y. and Kogure, Y. 2014. Ophiuroids (Echinodermata) collected by the R/V Mizuho-Maru from the continental shelf in the Sea of Japan. National Museum of Nature and Science Monographs, 44, 205-223.

Fukao, R. 1980. Review of Japanese fishes of the genus Neoclinus with description of two new species and notes on habitat preference. Publications of the Seto Marine Biological Laboratory, 25, 175-209.

Gosliner, M. T., Valdés, Á. and Behrens, D. W. 2015. Nudibranch and Sea Slug Identification Indo-Pacific. New World Publications, Florida, 408 pp.

Gray, J. S., Gray, C. B. P., Ugland, K. I., Wilson, R. S., Olsgard, F. and Johannessen, Ø. 1997. Coastal and deep-sea benthic diversities compared. Marine Ecology Progress Series, 159, 97-103.

Habe, T. and Kosuge, S. 1968. Distributional features of the marine molluscan fauna of Rikuchu Coast, Iwate Prefecture. Memories of the National Science Museum, 1, 145-147. (In Japanese)

Habe, T. 1976. Parasitic gastropods from Echinoderms of Japan. Bulletin of the National Science Museum. Series A (Zoology), 2 (3), 157-171.

Hamada, T. 2010. The Shells of Oita Prefecture. Ono High-speed Publishing, Oita, 136 pp. (In Japanese)

Hasegawa, K. 2001. Deep-sea gastropods of Tosa Bay, Japan, collected by the R/V Kotaka-Maru and Tansei-Maru during the years 1997-2000. National Science Museum Monographs, 20, 121-165.

Hasegawa, K. 2005. A preliminary list of deep-sea gastropods collected from the Nansei Islands, southwestern Japan. National Science Museum Monographs, 29, 137-190.

Ikebe, S. 2006. Catalog of molluscan shells collection donated by Mr. Shinichi Ikebe to the Wakayama Prefectural Museum of Natural History. Wakayama Prefectural Museum of Natural History, Wakayama, 164 pp. (In Japanese)

Ikebe, S. 2008. Shells of Wakayama Prefecture. Daiko Publish, Wakayama, 94 pp. (In Japanese)

Imajima, M. 1996. Annelida, Polychaeta I. Seibutsu Kenkyusha, Tokyo, 530 pp. (In Japanese)

Imajima, M. 2001. Annelida, Polychaeta II. Seibutsu Kenkyusha, Tokyo, 542 pp. (In Japanese)

Imajima, M. 2007. Annelida, Polychaeta III. Seibutsu Kenkyusha, Tokyo, 499 pp. (In Japanese)

Imajima, M. 2015. Annelida, Polychaeta IV. Seibutsu Kenkyusha, Tokyo, 332 pp. (In Japanese)

Imaoka, T. 1995. Holothuroidea. In, Nishikawa, S. (ed.) Guide to Seashore Animals of Japan with Color

Pictures and Keys. Vol. II., Hoikusha, Osaka, pp. 553-572. (In Japanese)

Irimura, S. 1969. Supplemental report of Dr. Murakami's paper on the ophiurans of Amakusa, Kyushu. Publications from the Amakusa Marine Biological Laboratory, Kyushu University, 2 (1), 37-48. 


\section{MASANORI OKANISHI ET AL.}

Irimura, S. 1981. Ophiurans from Tanabe Bay and its vicinity, with the description of a new species of Ophiocentrus. Publications of the Seto Marine Biological Laboratory, 26 (1), 15-49.

Irimura, S. 1982. The brittle-stars of Sagami Bay. Biological Laboratory, Imperial Household, Tokyo, 95 pp.

Irimura, S. 1990. Ophiuroidea. In, Japan Fisheries Resource Conservation Association (ed.) Echinoderms from Continental Shelf and Slope around Japan, Volume 1, Japan Fisheries Resource Conservation Association, Tokyo, pp. 111-152.

Irimura, S. 1991. Ophiuroidea. In, Japan Fisheries Resource Conservation Association (ed.) Echinoderms from Continental Shelf and Slope around Japan, Volume 2, Japan Fisheries Resource Conservation Association, Tokyo, pp. 65-100.

Irimura, S. and Kubodera, T. 1998. Ophiuroidea in the East China Sea. Memoirs of the National Science Museum, Tokyo, 30, 135-143.

Irimura, S., Fujita, T. and Ueshima, R. 2001. Preliminary report on the ophiuroids (Echinodermata) on the shelf off Shimoda, South of Izu Peninsula, Central Japan. Memoirs of the National Museum of Nature and Science, 37, 311-315.

Irimura, S. and Tachikawa, H. 2003. Ophiuroids from the Ogasawara Islands (Echinodermata: Ophiuroidea). Ogasawara Research, 28, 1-27.

Ishida, Y., Ohtsuka, S., Takayasu, K., Kobayashi, I., Lee, Y., Seto., K., Tanaka, H., Tamura, K., Go, A. and Nakaguchi, K. 2001. Preliminary faunistic survey of ophiuroids in the westernmost part of the Sea of Japan. Journal of the Faculty of Applied Biological Science, Hiroshima University, 40, 1-14.

Jimi, N., Tanaka, M. and Fujiwara, Y. 2016. Diplocirrus nicolaji (Annelida: Flabelligeridae) from Japan, detailed morphological observation and DNA barcoding. Marine Biodiversity Records, 9 (22), doi: 10.1186/s41200-016-0024-7.

Kroh, A. and Smith, A. B. 2010. Classification and phylogeny of post-Palaeozoic echinoids. Journal of Systematic Palaeontology, 7, 147-212.

Kuwamura, T. 1980. Seasonal occurrence of fishes at inshore rocky reefs in Shirahama, southern Japan. Japanese Journal of Ichthyology, 27, 243-248. (In Japanese)

Levin, L. A., Etter R. J., Rex M. A., Gooday, A. J., Smith, C. R., Pineda, J., Stuart, C. T., Hessler, R. R. and Pawson, D. 2001. Environmental influences on regional deep-sea species diversity. Annual Review of Ecology and Systematics, 32, 51-93.

Litvinova, N. M. 2001. The ophiuroid genus Ophiomyces (Echinodermata, Ophiuroidea). In, Kuznetsov, A. P. and Zezina, O. N. (eds.), Composition and Structure of the Marine Bottom Biota: Collected Proceedings, VNIRO Publishing House, Moscow, pp. 145-158.

Massin, C., Wittoeck, J., and Hostens, K. 2014. Leptosynapta inhaerens (OF Müller, 1776) (Echinodermata, Holothuroiea): A new record for the Belgian marine waters. Belgian Journal of Zoology, 144 (2), $112-$ 119.

Matsumoto H. 1917. A monograph of Japanese Ophiuroidea, arranged according to a new classification. The Journal of the College of Science, Imperial University of Tokyo, Japan, 38, 1-408.

Murakami, S. 1943. Ophiurans from some gulfs and bays of Nippon. Journal of the Department of Agriculture, Kyusyu Imperial University, 7 (6), 223-234.

Murakami, S. 1944. Report on the ophiurans from off Ogasawara Islands and from off the Yaéyama group, Nippon. Journal of the Department of Agriculture, Kyushu Imperial University, 7, 235-257.

Nakabo, T. (ed.). 2013. Fishes of Japan with Pictorial Keys to the Species, Third Edition. Tokai University Press, Kanagawa, 2428 pp. (In Japanese)

Nakabo, T. and Kai, Y. 2013. Bregmacerotidae. In, Nakabo, T. (ed.), Fishes of Japan with Pictorial Keys to the Species, Third Edition, Tokai University Press, Kanagawa, pp. 491-492. (In Japanese)

Nakabo, T. and Nakayama, K. 2013. Introduction to ichthyology 3rd ed. In: Nakabo, T. (ed.), Fishes of Japan with Pictorial Keys to the Species, Third Edition, Tokai University Press, Kanagawa, pp. 2-30. (In Japanese) 
Nakano, H., Kakui, K., Kajihara, H., Shimomura, M., Jimi, N., Tomioka, S., Tanaka, H., Yamasaki, H., Tanaka, M., Izumi, T., Okanishi, M., Yamada, Y., Shinagawa, H., Sato, T., Tsuchiya, Y., Omori, A., Sekifuji, M. and Kohtsuka, H., 2015. JAMBIO Coastal Organism Joint Surveys reveals undiscovered biodiversity around Sagami Bay. Regional Studies in Marine Science, 2 (Suppl.), 77-81.

Nakayama, T. 2000. Descriptions of a new subgenus, fourteen new species, and three substituted names of Epitoniids from Japan (Gastropoda: Epitoniidae). Venus, 59 (4), 277-292.

Nakayama, T. 2003. A review of northwest Pacific Epitoniids (Gastropoda: Epitoniidae). Monographs of Marine Mollusca, 6, $143 \mathrm{pp}$.

Namikawa, H., 2008. Recent developments in the faunal surveys of Sagami Bay. In, Okada, H., Mawatari, S. F., Suzuki, N. and Gautam, P. (eds.), Origin and Evolution of Natural Diversity, 21st Century COE for Neo-Science of Natural History. Hokkaido University, Sapporo, pp. 125-127.

National Science Museum 1997. Deep-sea fauna and pollutants in Suruga Bay. National Science Museum Monograph, 12, $336 \mathrm{pp}$.

National Science Museum 2001. Deep-sea fauna and pollutants in Tosa Bay. National Science Museum Monograph, 20, $380 \mathrm{pp}$.

National Science Museum 2005. Deep-sea fauna and pollutants in Nansei Islands. National Science Museum Monograph, 29, 476 pp.

National Museum of Nature and Science 2009. Deep-sea fauna and pollutants off Pacific coast of northern Japan. National Museum of Nature and Science Monograph, 39, 755 pp.

National Museum of Nature and Science 2014. Deep-sea fauna of the Sea of Japan. National Science Museum Monograph, 44, $291 \mathrm{pp}$.

Nishi, E., Tanaka, K., Sato, M. and Kudo, T. 2004. First record of Owenia godson Koh \& Bhaud, 2001

(Polychaeta, Oweniidae) from the seagrass bed of Odawa Bay, Miura Peninsula, Japan. Nanki Seibutu, 46 (2), pp. 121-122. (In Japanese)

Noda, H. 1985. Description of a new subspecies of Angursa biscupis Pollock (Heterotardigrada, Halechiniscidae) from Tanabe Bay, Japan. Publications of the Seto Marine Biological Laboratory, 30, 269-276.

Noda, H. 1987. A new species of marine Tardigrada of the genus Florarctus (Heterotardigrada, Halechiniscidae) from Japan. Publications of the Seto Marine Biological Laboratory, 32, 323-328.

Noda, H. 1994. Tardigrades from sand beaches in Okinawa. Proceedings of Japanese Society of Systematic Zoology, 51, 79. (Published conference abstract in Japanese)

Ohgaki, S. 2011. Long-term dynamics of coastal marine biota: a scientific natural history of Tanabe Bay. The Nanki Laboratory of Coastal Marine Ecology, Tanabe, Japan, 136 pp. (In Japanese)

Ohshima, H. 1915-1918. Holothuroidea in northwest Pacific. 1-20. Dobutsugaku zasshi, 28-31. (In Japanese)

Okanishi, M. and Fujita, T. 2013, Molecular phylogeny based on increased number of species and genes revealed more robust family-level systematics of the order Euryalida (Echinodermata: Ophiuroidea): Molecular Phylogenetics and Evolution, 69, 566-580.

Okanishi, M. Moritaki, T. and Fujita, T. 2014. Redescription of an euryalid brittle star, Astroceras coniunctum (Echinodermata, Ophiuroidea, Euryalida). Bulletin of the National Museum of Nature and Science, Series A (Zoology), 40 (3), 133-139.

Okutani, T. (ed.). 2000. Marine Mollusks in Japan. Tokai University Press, Kanagawa, 1173 pp.

Oskars, T. R., Bouchet, P. and Malaquias, M. A. E. 2015. A new phylogeny of the Cephalaspidea (Gastropoda: Heterobranchia) based on expanded taxon sampling and gene markers. Molecular Phylogenetics and Evolution, 89, 130-150.

Rex, M. A., Stuart, C. T. and Coyne, G. 2000. Latitudinal gradients of species richness in the deep-sea benthos of the North Atlantic. Proceedings of the National Academy of Sciences of the United States of America, 97, 4082-4085. 


\section{MASANORI OKANISHI ET AL.}

Rouse, G.W. and Pleijel, F. 2001. Polychaetes. Oxford University Press, Oxford, 354 pp.

Rowe, F.W.E. and Gates, J. 1995. Echinodermata. In, Wells, A. (ed.) Zoological Catalogue of Australia. Vol. 33. CSIRO, Melbourne, $510 \mathrm{pp}$.

Saba, M., Tomida, Y. and Kimoto, T. 1982. Echinoderms fauna of Ise Bay, and the northern and the middle parts of Kumano Nada. Bulletin of the Mie Prefectural Museum Natural Science, 4, 1-82. (In Japanese with English summary)

Sanders, H. S. 1968. Marine benthic diversity: a comparative study. American Naturalist, 102, 243-282.

Shigei, M. 1981. A study on the echinoid fauna of the East China Sea and the coastal waters of southern Korea, Kyushu, Ryukyu, and Taiwan. Publications of the Seto Marine Biological Laboratory, 26, 191241.

Shigei, M. 1986. The Sea Urchins of Sagami Bay. Maruzen, Tokyo, 204 pp.

Tsuchida, E. 2000. Epitoniidae. In, Okutani, T. (ed.) Marine Mollusks in Japan. Tokai University Press, Kanagawa, pp. 320-343.

Uchida, H. 1992. Annelida, Polychaeta. In, Nishimura, S. (ed.) Genshoku Kensaku Nihon Kaigan Doubutsu Zukan. Vol. I. [Guide to Seashore Animals of Japan with Color Pictures and Keys. Vol. I.], Hoikusha, Osaka, pp. 310-373. (In Japanese)

Utinomi, H. 1952. Polychaeta and Bryzoa from off Minabe. The Nanki Seibutu, 4 (3-4), 98-105. (In Japanese)

Utinomi, H. 1965. Holothuroidea. In, Okada, Y., Uchida, S. and Uchida, T. (eds.) Shin Nihon Doubutsu Zukan. Vol. III. [New Illustrated Encyclopedia of the Fauna of Japan Vol. III], Hokuryukan, Tokyo, pp. 82-99. (In Japanese)

Uyeno, D. 2015. Systematic revision of the pennellid genus Creopelates Shiino, 1958 (Copepoda: Siphonostomatoida) and the proposal of a new genus. Zootaxa, 3904, 359-386.

Wessel, P., Smith, W. H. F., Scharroo, R., Luis, J. and Wobbe, F. 2013. Generic Mapping Tools: improved version released. Eos Transactions American Geophysical Union, 94, 409-410.

World Register of Marine Species (WoRMS). http://www.marinespecies.org (accessed 21.04.16)

Yamada, U. and Yagishita, N. 2013. Cynoglossidae. In, Nakabo (ed.) Fishes of Japan with Pictorial Keys to the Species, Third Edition, Tokai University Press, Kanagawa, pp. 1693-1698. (In Japanese)

Yamamoto, T. 1971. A new species of Primovula from Japan, parasitic to a Gorgonid (Gastropoda: Ovulidae). Publications of the Seto Marine Biological Laboratory, 19 (4), 191-195.

Yanagisawa, Y. 1978. Studies on the interspecific relationship between Gobiid fish and snapping shrimp. I. Gobiid fishes associated with snapping shrimps in Japan. Publications of the Seto Marine Biological Laboratory, 24 (4-6), 269-325.

Yoshida, R., Hirose, M. and Hirose, E. 2013. A new peltogastrid rhizocephalan parasitising a hermit crab from the Japanese coast: a second species of Dipterosaccus Van Kampen \& Boschma, 1925 (Crustacea: Cirripedia). Systematic Parasitology, 84 (2), 137-147.

Zayasu, Y., Nomura, K., Seno, K., and Asakura, A. 2013. A new species of Fizesereneia Takeda \& Tamura, 1980 (Crustacea: Decapoda: Brachyura: Cryptochiridae) from Japan. Zootaxa, 3681 (3), 257-269.

Received: 26 July2016

Accepted: 12 November 2016

Published online: 7 December 2016 


\section{BENTHIC FAUNA OF SHIRAHAMA}

Table 1. Sampling sites of Shirahama Marine Research. Asterisks indicate that the data is not recorded. Circles in "Animal" column indicatestations where listed animals were collected. Abbreviations: DMB, Dredge for meio-benthos; J, Janthina; KD, Kamiya-type dredge; SMBS, Smith McIntyre bottom grab sampler; Z, Zoea; 50BD, $50 \mathrm{~cm}$-front biological dredge.

\begin{tabular}{|c|c|c|c|c|c|c|c|c|c|c|c|}
\hline \multirow{2}{*}{$\frac{\text { Station }}{\text { SMR12-01-1 }}$} & Date & \multirow{2}{*}{$\frac{\text { Gear }}{\mathrm{DMB}}$} & \multicolumn{3}{|c|}{ Position in } & \multicolumn{3}{|c|}{ Position out } & \multirow{2}{*}{$\begin{array}{c}\begin{array}{c}\text { Depth } \\
(\mathrm{m})\end{array} \\
433\end{array}$} & \multirow{2}{*}{$\frac{\text { Animal }}{-}$} & \multirow{2}{*}{$\frac{\text { Vehicle }}{\mathrm{J}}$} \\
\hline & 13 November 2012 & & $33^{\circ} 3$ & $36.2119^{\prime} \mathrm{N} 135^{\circ} 16$ & $6.8795^{\prime} \mathrm{E}$ & * & & & & & \\
\hline SMR12-01-2 & 13 November 2012 & DMB & $33^{\circ} 3$ & $36.5307^{\prime} \mathrm{N} 135^{\circ} 16$ & $6.3168^{\prime} \mathrm{E}$ & * & & & 308 & - & $J$ \\
\hline SMR13-01-1 & 17 June 2013 & $\mathrm{KD}$ & $33^{\circ}$ & $37.6120^{\prime} \mathrm{N} 135^{\circ}$ & $37.6120^{\prime} \mathrm{E}$ & $33^{\circ}$ & $37.7880^{\prime} \mathrm{N} 135^{\circ}$ & $37.7580^{\prime} \mathrm{E}$ & $93-93$ & $\bigcirc$ & J \\
\hline SMR13-01-2 & 17 June 2013 & $\mathrm{KD}$ & $33^{\circ}$ & $36.6470^{\prime} \mathrm{N} 135^{\circ}$ & $36.4690^{\prime} \mathrm{E}$ & $33^{\circ}$ & $37.0540^{\prime} \mathrm{N} 135^{\circ}$ & $37.1680^{\prime} \mathrm{E}$ & $193-210$ & $\bigcirc$ & $J$ \\
\hline SMR13-02-1 & 6 August 2013 & $\mathrm{KD}$ & $33^{\circ}$ & $36.4166^{\prime} \mathrm{N} 135^{\circ}$ & $17.6333^{\prime} \mathrm{E}$ & $*$ & & & 229 & $\bigcirc$ & $\mathrm{J}$ \\
\hline SMR13-02-2 & 6 August 2013 & $\mathrm{KD}$ & $33^{\circ}$ & $38.6918^{\prime} \mathrm{N} 135^{\circ}$ & $18.6252^{\prime} \mathrm{E}$ & $*$ & & & 81 & $\bigcirc$ & J \\
\hline SMR13-02-3 & 6 August 2013 & $\mathrm{KD}$ & $33^{\circ}$ & $39.9071^{\prime} \mathrm{N} 135^{\circ}$ & $19.0499^{\prime} \mathrm{E}$ & $*$ & & & 57 & 0 & J \\
\hline SMR13-03-1 & 17 September 2013 & $\mathrm{KD}$ & $33^{\circ}$ & $40.3175^{\prime} \mathrm{N} 135^{\circ}$ & $18.7006^{\prime} \mathrm{E}$ & $33^{\circ}$ & $40.7639^{\prime} \mathrm{N} 135^{\circ}$ & $18.6803^{\prime} \mathrm{E}$ & $50.5-45.6$ & $\bigcirc$ & $\mathrm{J}$ \\
\hline SMR13-03-2 & 17 September 2013 & $\mathrm{KD}$ & $33^{\circ}$ & $40.9550^{\prime} \mathrm{N} 135^{\circ}$ & $18.6452^{\prime} \mathrm{E}$ & $33^{\circ}$ & $41.0281^{\prime} \mathrm{N} 135^{\circ}$ & $18.6412^{\prime} \mathrm{E}$ & $44.1-43.2$ & $\bigcirc$ & $\mathrm{J}$ \\
\hline SMR13-03-3 & 17 September 2013 & $\mathrm{KD}$ & $33^{\circ}$ & $42.1314^{\prime} \mathrm{N} 135^{\circ}$ & $19.0022^{\prime} \mathrm{E}$ & $33^{\circ}$ & $42.1950^{\prime} \mathrm{N} 135^{\circ}$ & $18.9689^{\prime} \mathrm{E}$ & $42.3-42.2$ & $\bigcirc$ & $\mathrm{J}$ \\
\hline SMR13-03-4 & 17 September 2013 & $\mathrm{KD}$ & $33^{\circ}$ & $43.5214^{\prime} \mathrm{N} 135^{\circ}$ & $19.0838^{\prime} \mathrm{E}$ & $33^{\circ}$ & $43.5665^{\prime} \mathrm{N} 135^{\circ}$ & $19.1056^{\prime} \mathrm{E}$ & $31.1-30.4$ & $\bigcirc$ & J \\
\hline SMR13-03-5 & 17 September 2013 & $\mathrm{KD}$ & $33^{\circ}$ & $43.5631^{\prime} \mathrm{N} 135^{\circ}$ & $19.0788^{\prime} \mathrm{E}$ & $33^{\circ}$ & $43.5752^{\prime} \mathrm{N} 135^{\circ}$ & $19.1454^{\prime} \mathrm{E}$ & $30.6-30$ & $\bigcirc$ & $J$ \\
\hline SMR13-04-1 & 18 September 2013 & $\mathrm{KD}$ & $33^{\circ}$ & $37.3342^{\prime} \mathrm{N} 135^{\circ}$ & $16.5923^{\prime} \mathrm{E}$ & $33^{\circ}$ & $37.6309^{\prime} \mathrm{N} 135^{\circ}$ & $16.4962^{\prime} \mathrm{E}$ & $175-137$ & 0 & $\mathrm{~J}$ \\
\hline SMR13-04-2 & 18 September 2013 & $\mathrm{KD}$ & $33^{\circ}$ & $37.5253^{\prime} \mathrm{N} 135^{\circ}$ & $16.4122^{\prime} \mathrm{E}$ & $33^{\circ}$ & $37.7639^{\prime} \mathrm{N} 135^{\circ}$ & $16.1896^{\prime} \mathrm{E}$ & $146-139$ & $\bigcirc$ & J \\
\hline SMR14-01-1 & 7 May 2014 & DMB & $33^{\circ}$ & $36.7552^{\prime} \mathrm{N} 135^{\circ}$ & $16.4591^{\prime} \mathrm{E}$ & $33^{\circ}$ & $36.8406^{\prime} \mathrm{N} 135^{\circ}$ & $16.6968^{\prime} \mathrm{E}$ & $184-167$ & $\bigcirc$ & J \\
\hline SMR14-01-2 & 7 May 2014 & $\mathrm{KD}$ & $33^{\circ}$ & $36.6761^{\prime} \mathrm{N} 135^{\circ}$ & $18.8216^{\prime} \mathrm{E}$ & $33^{\circ}$ & $36.8519^{\prime} \mathrm{N} 135^{\circ}$ & $18.1623^{\prime} \mathrm{E}$ & $194-173$ & - & $\mathrm{J}$ \\
\hline SMR14-01-3 & 7 May 2014 & DMB & $33^{\circ}$ & $39.7600^{\prime} \mathrm{N} 135^{\circ}$ & $16.5928^{\prime} \mathrm{E}$ & $33^{\circ}$ & $39.8859^{\prime} \mathrm{N} 135^{\circ}$ & $16.5602^{\prime} \mathrm{E}$ & $68.3-67.5$ & - & $\mathrm{J}$ \\
\hline SMR14-02-1 & 8 May 2014 & DMB & $33^{\circ}$ & $43.8640^{\prime} \mathrm{N} 135^{\circ}$ & $19.8363^{\prime} \mathrm{E}$ & $33^{\circ}$ & $43.8880^{\prime} \mathrm{N} 135^{\circ}$ & $19.7870^{\prime} \mathrm{E}$ & $22.7-22.6$ & - & $J$ \\
\hline SMR14-02-2 & 8 May 2014 & $\mathrm{DMB}$ & $33^{\circ}$ & $43.5374^{\prime} \mathrm{N} 135^{\circ}$ & $20.39866^{\prime} \mathrm{E}$ & $33^{\circ}$ & $43.6092^{\prime} \mathrm{N} 135^{\circ}$ & $20.3589^{\prime} \mathrm{E}$ & $21.7-21.3$ & - & J \\
\hline SMR14-03-1 & 21 October 2014 & $\mathrm{KD}$ & $33^{\circ}$ & $35.5408^{\prime} \mathrm{N} 135^{\circ}$ & $17.0150^{\prime} \mathrm{E}$ & $33^{\circ}$ & $36.8196^{\prime} \mathrm{N} 135^{\circ}$ & $16.9003^{\prime} \mathrm{E}$ & $286-169$ & - & $J$ \\
\hline SMR14-03-2 & 21 October 2014 & $\mathrm{KD}$ & $33^{\circ}$ & $38.1577^{\prime} \mathrm{N} 135^{\circ}$ & $17.4542^{\prime} \mathrm{E}$ & $33^{\circ}$ & $38.3688^{\prime} \mathrm{N} 135^{\circ}$ & $17.3500^{\prime} \mathrm{E}$ & $104-104$ & - & $\mathrm{J}$ \\
\hline SMR14-03-3 & 21 October 2014 & $\mathrm{KD}$ & $33^{\circ}$ & $38.1651^{\prime} \mathrm{N} 135^{\circ}$ & $17.4272^{\prime} \mathrm{E}$ & $33^{\circ}$ & $38.3150^{\prime} \mathrm{N} 135^{\circ}$ & $17.3583^{\prime} \mathrm{E}$ & $104-104$ & - & J \\
\hline SMR14-03-4 & 21 October 2014 & $\mathrm{KD}$ & $33^{\circ}$ & $40.8917^{\prime} \mathrm{N} 135^{\circ}$ & $17.2333^{\prime} \mathrm{E}$ & $33^{\circ}$ & $41.0833^{\prime} \mathrm{N} 135^{\circ}$ & $17.0722^{\prime} \mathrm{E}$ & $74-74$ & ○ & J \\
\hline SMR15-01-1 & 14 April 2015 & $\mathrm{KD}$ & $33^{\circ}$ & $39.4563^{\prime} \mathrm{N} 135^{\circ}$ & $18.3679^{\prime} \mathrm{E}$ & $33^{\circ}$ & $39.9469^{\prime} \mathrm{N} 135^{\circ}$ & $17.9586^{\prime} \mathrm{E}$ & $76.1-75.8$ & $\bigcirc$ & $\mathrm{J}$ \\
\hline SMR15-01-2 & 14 April 2015 & $\mathrm{KD}$ & $33^{\circ}$ & $40.3133^{\prime} \mathrm{N} 135^{\circ}$ & $18.2067^{\prime} \mathrm{E}$ & $33^{\circ}$ & $40.6207^{\prime} \mathrm{N} 135^{\circ}$ & $17.9691 ' \mathrm{E}$ & $66.7-65.6$ & $\bigcirc$ & $J$ \\
\hline SMR15-02-1 & 27 April 2015 & $\mathrm{KD}$ & $33^{\circ}$ & $36.5297^{\prime} \mathrm{N} 135^{\circ}$ & $15.9027^{\prime} \mathrm{E}$ & $33^{\circ}$ & $37.03011^{\prime} \mathrm{N} 135^{\circ}$ & $15.2931 ' \mathrm{E}$ & $295-217$ & $\bigcirc$ & $J$ \\
\hline SMR15-02-2 & 27 April 2015 & $\mathrm{KD}$ & $33^{\circ}$ & $37.2618^{\prime} \mathrm{N} 135^{\circ}$ & $15.1607^{\prime} \mathrm{E}$ & $33^{\circ}$ & $37.6507^{\prime} \mathrm{N} 135^{\circ}$ & $14.7445^{\prime} \mathrm{E}$ & $180-173$ & $\bigcirc$ & J \\
\hline SMR15-02-3 & 27 April 2015 & $\mathrm{KD}$ & $33^{\circ}$ & $37.7698^{\prime} \mathrm{N} 135^{\circ}$ & $14.6279^{\prime} \mathrm{E}$ & $33^{\circ}$ & $37.9290^{\prime} \mathrm{N} 135^{\circ}$ & $14.5255^{\prime} \mathrm{E}$ & $188-247$ & $\bigcirc$ & $J$ \\
\hline SMR15-03-1 & 22 May 2015 & $50 \mathrm{BD}$ & $33^{\circ}$ & $37.2991^{\prime} \mathrm{N} 135^{\circ}$ & $15.1098^{\prime} \mathrm{E}$ & $33^{\circ}$ & $37.4010^{\prime} \mathrm{N} 135^{\circ}$ & $14.9560^{\prime} \mathrm{E}$ & $177-175$ & $\bigcirc$ & $J$ \\
\hline SMR15-03-2 & 22 May 2015 & $50 \mathrm{BD}$ & $33^{\circ}$ & $38.7078^{\prime} \mathrm{N} 135^{\circ}$ & $15.5414^{\prime} \mathrm{E}$ & $33^{\circ}$ & $38.8776^{\prime} \mathrm{N} 135^{\circ}$ & $15.5309^{\prime} \mathrm{E}$ & $128-124$ & O & J \\
\hline SMR15-03-3 & 22 May 2015 & $50 \mathrm{BD}$ & $33^{\circ}$ & $39.5157^{\prime} \mathrm{N} 135^{\circ}$ & $18.3230 ' \mathrm{E}$ & $33^{\circ}$ & $39.7289^{\prime} \mathrm{N} 135^{\circ}$ & $18.2344^{\prime} \mathrm{E}$ & $75-73.4$ & $\bigcirc$ & $J$ \\
\hline SMR15-04-1 & 27 May 2015 & $50 \mathrm{BD}$ & $33^{\circ}$ & $37.5484^{\prime} \mathrm{N} 135^{\circ}$ & $14.8603^{\prime} \mathrm{E}$ & $33^{\circ}$ & $37.5755^{\prime} \mathrm{N} 135^{\circ}$ & $14.9760^{\prime} \mathrm{E}$ & $169-164$ & $\bigcirc$ & $\mathrm{J}$ \\
\hline SMR15-04-2 & 27 May 2015 & $50 \mathrm{BD}$ & $33^{\circ}$ & $38.8328^{\prime} \mathrm{N} 135^{\circ}$ & $15.4698^{\prime} \mathrm{E}$ & $33^{\circ}$ & $38.8929^{\prime} \mathrm{N} 135^{\circ}$ & $15.4997 ' \mathrm{E}$ & $126-124$ & $\bigcirc$ & $J$ \\
\hline SMR15-04-3 & 27 May 2015 & $50 \mathrm{BD}$ & $33^{\circ}$ & $39.7547^{\prime} \mathrm{N} 135^{\circ}$ & $18.1521^{\prime} \mathrm{E}$ & $33^{\circ}$ & $40.1084^{\prime} \mathrm{N} 135^{\circ}$ & $18.0326^{\prime} \mathrm{E}$ & $75-72$ & ○ & $J$ \\
\hline SMR15-04-4 & 27 May 2015 & $50 \mathrm{BD}$ & $33^{\circ}$ & $42.2404^{\prime} \mathrm{N} 135^{\circ}$ & $20.5134^{\prime} \mathrm{E}$ & $33^{\circ}$ & $42.6522^{\prime} \mathrm{N} 135^{\circ}$ & $20.6508^{\prime} \mathrm{E}$ & $31-30$ & O & J \\
\hline SMR15-05-1 & 28 May 2015 & SMBS & $33^{\circ}$ & $42.4482^{\prime} \mathrm{N} 135^{\circ}$ & $22.8197^{\prime} \mathrm{E}$ & * & & & 13.2 & $\bigcirc$ & $J$ \\
\hline SMR15-05-2 & 28 May 2015 & SMBS & $33^{\circ}$ & $41.6617^{\prime} \mathrm{N} 135^{\circ}$ & $21.7451^{\prime} \mathrm{E}$ & * & & & 3.7 & $\bigcirc$ & $J$ \\
\hline SMR15-05-3 & 28 May 2015 & DMB & $33^{\circ}$ & $41.6386^{\prime} \mathrm{N} 135^{\circ}$ & $21.7664^{\prime} \mathrm{E}$ & $*$ & & & 7.7 & $\bigcirc$ & J \\
\hline SMR15-06-1 & 12 June 2015 & SMBS & $33^{\circ}$ & $42.20^{\prime} \mathrm{N} 135^{\circ} 2$ & $0.13^{\prime} \mathrm{E}$ & $33^{\circ}$ & $42.20^{\prime} \mathrm{N} 135^{\circ} 20$ & $0.13^{\prime} \mathrm{E}$ & $34-34$ & O & Z \\
\hline SMR15-06-2 & 12 June 2015 & SMBS & $33^{\circ}$ & $41.52^{\prime} \mathrm{N} 135^{\circ} 2$ & $1.32 ' \mathrm{E}$ & $33^{\circ}$ & $41.52^{\prime} \mathrm{N} 135^{\circ} 2$ & $1.32^{\prime} \mathrm{E}$ & $5-5$ & ○ & $\mathrm{Z}$ \\
\hline SMR15-06-3 & 12 June 2015 & SMBS & $33^{\circ}$ & $41.41^{\prime} \mathrm{N} 135^{\circ} 2$ & 1.44'E & $33^{\circ}$ & $41.41^{\prime} \mathrm{N} 135^{\circ} 2$ & $1.44^{\prime} \mathrm{E}$ & $4-4$ & - & Z \\
\hline SMR15-06-4 & 12 June 2015 & SMBS & $33^{\circ}$ & $41.47^{\prime} \mathrm{N} 135^{\circ} 2$ & $1.53^{\prime} \mathrm{E}$ & $33^{\circ}$ & $41.47^{\prime} \mathrm{N} 135^{\circ} 2$ & $1.53^{\prime} \mathrm{E}$ & $4-4$ & - & Z \\
\hline SMR15-07-1 & 29 June 2015 & $50 \mathrm{BD}$ & $33^{\circ}$ & $37.2768^{\prime} \mathrm{N} 135^{\circ}$ & $15.2148^{\prime} \mathrm{E}$ & $33^{\circ}$ & $37.1925^{\prime} \mathrm{N} 135^{\circ}$ & $15.3868^{\prime} \mathrm{E}$ & $175-175$ & $\bigcirc$ & J \\
\hline SMR15-07-2 & 29 June 2015 & $50 \mathrm{BD}$ & $33^{\circ}$ & $39.6232^{\prime} \mathrm{N} 135^{\circ}$ & $18.2800^{\prime} \mathrm{E}$ & $33^{\circ}$ & $39.49744^{\prime} \mathrm{N} 135^{\circ}$ & $18.4200^{\prime} \mathrm{E}$ & $74-73.5$ & $\bigcirc$ & $J$ \\
\hline SMR15-07-3 & 29 June 2015 & SMBS & $33^{\circ}$ & $39.5284^{\prime} \mathrm{N} 135^{\circ}$ & $18.5384^{\prime} \mathrm{E}$ & $33^{\circ}$ & $39.4536^{\prime} \mathrm{N} 135^{\circ}$ & $18.6925^{\prime} \mathrm{E}$ & $72.1-71.4$ & - & J \\
\hline SMR15-07-4 & 29 June 2015 & $50 \mathrm{BD}$ & $33^{\circ}$ & $40.4003^{\prime} \mathrm{N} 135^{\circ}$ & $18.0122^{\prime} \mathrm{E}$ & $33^{\circ}$ & $40.3763^{\prime} \mathrm{N} 135^{\circ}$ & $19.1354^{\prime} \mathrm{E}$ & $48.2-46.2$ & O & J \\
\hline SMR16-01-1 & 27 June 2016 & $50 \mathrm{BD}$ & $33^{\circ}$ & $40.6848^{\prime} \mathrm{N} 135^{\circ}$ & $18.0105^{\prime} \mathrm{E}$ & $33^{\circ}$ & $40.7101^{\prime} \mathrm{N} 135^{\circ}$ & $18.0539^{\prime} \mathrm{E}$ & $63-61.5$ & 0 & J \\
\hline
\end{tabular}




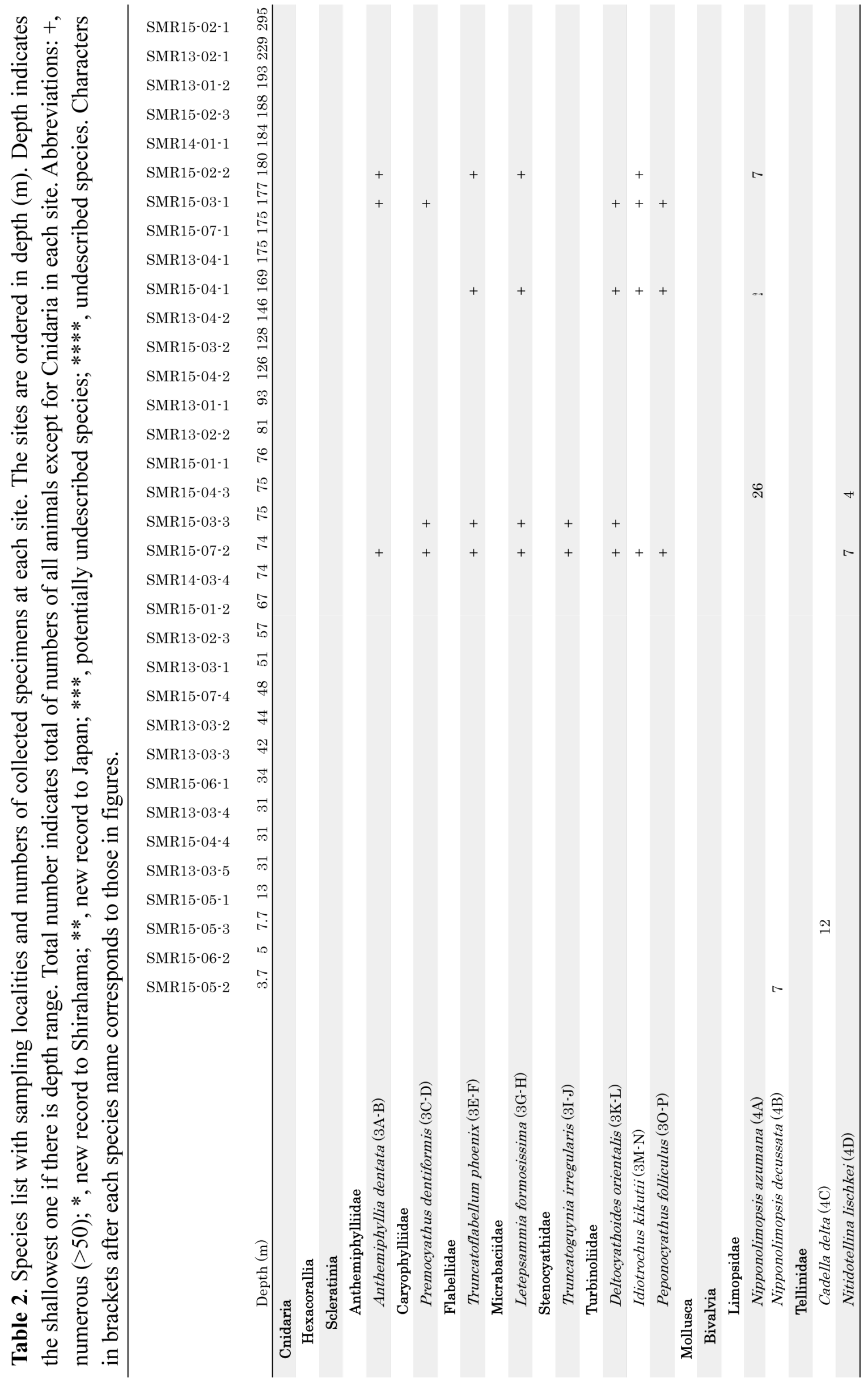




\section{BENTHIC FAUNA OF SHIRAHAMA}

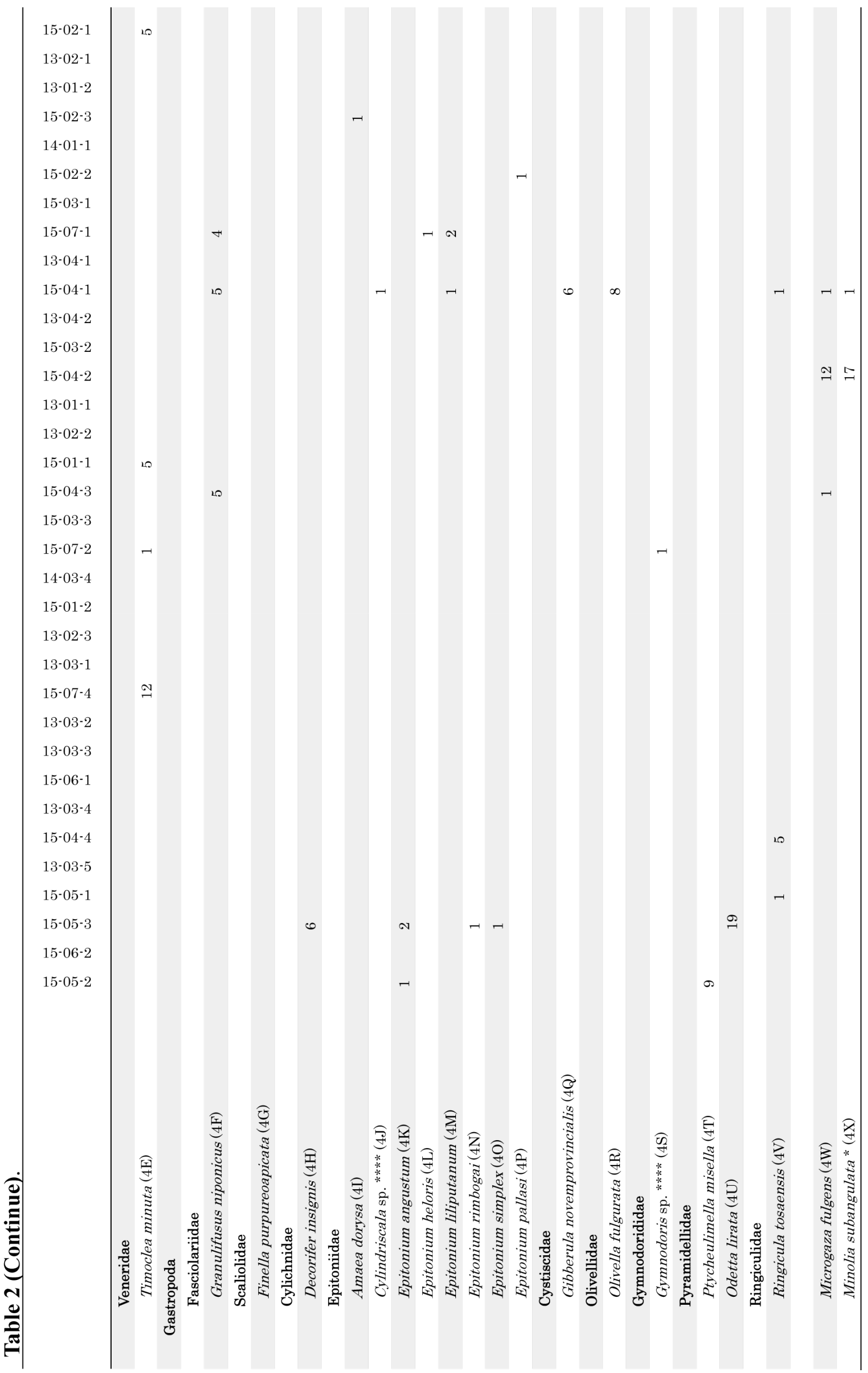


MASANORI OKANISHI ET AL.

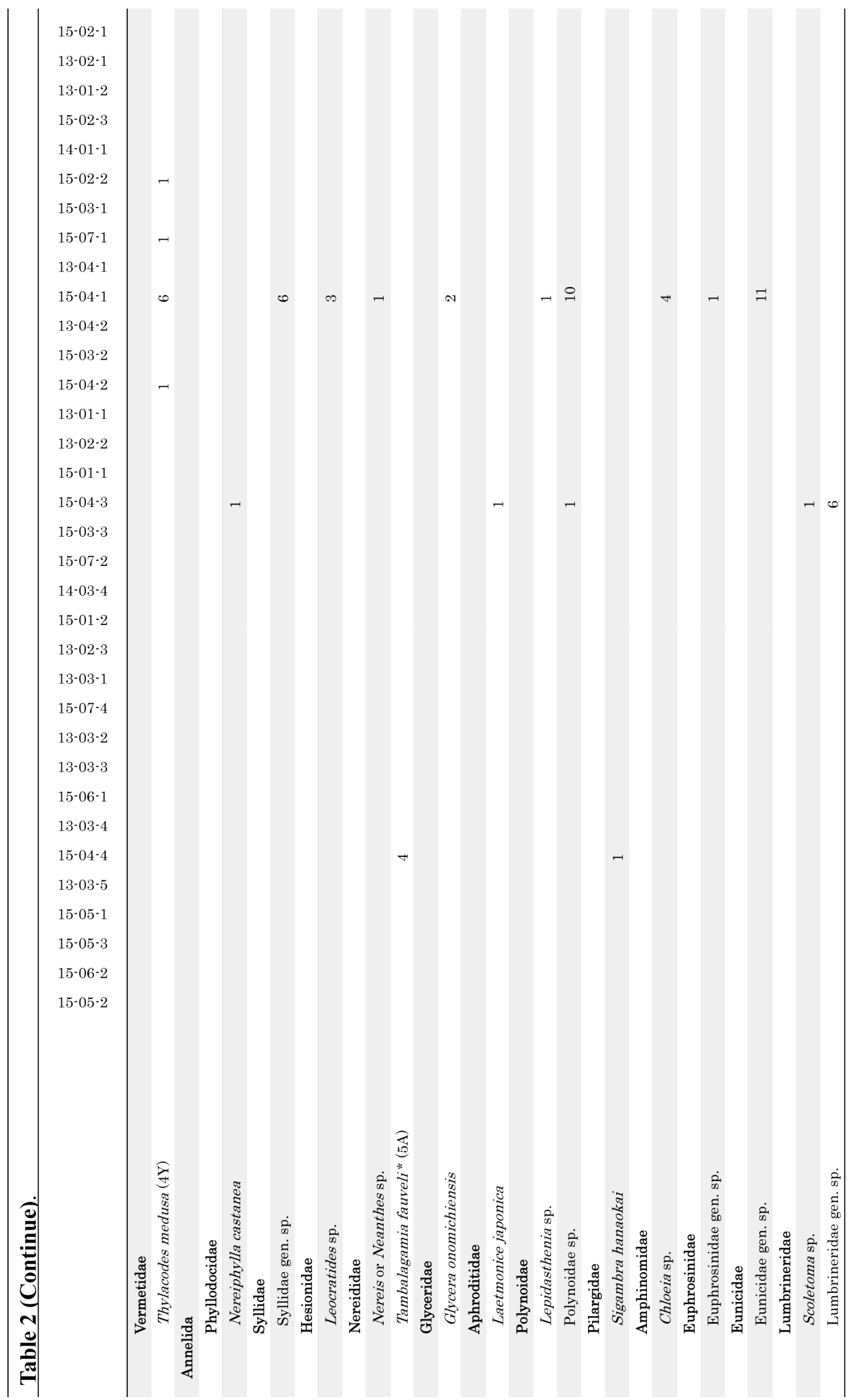


BENTHIC FAUNA OF SHIRAHAMA

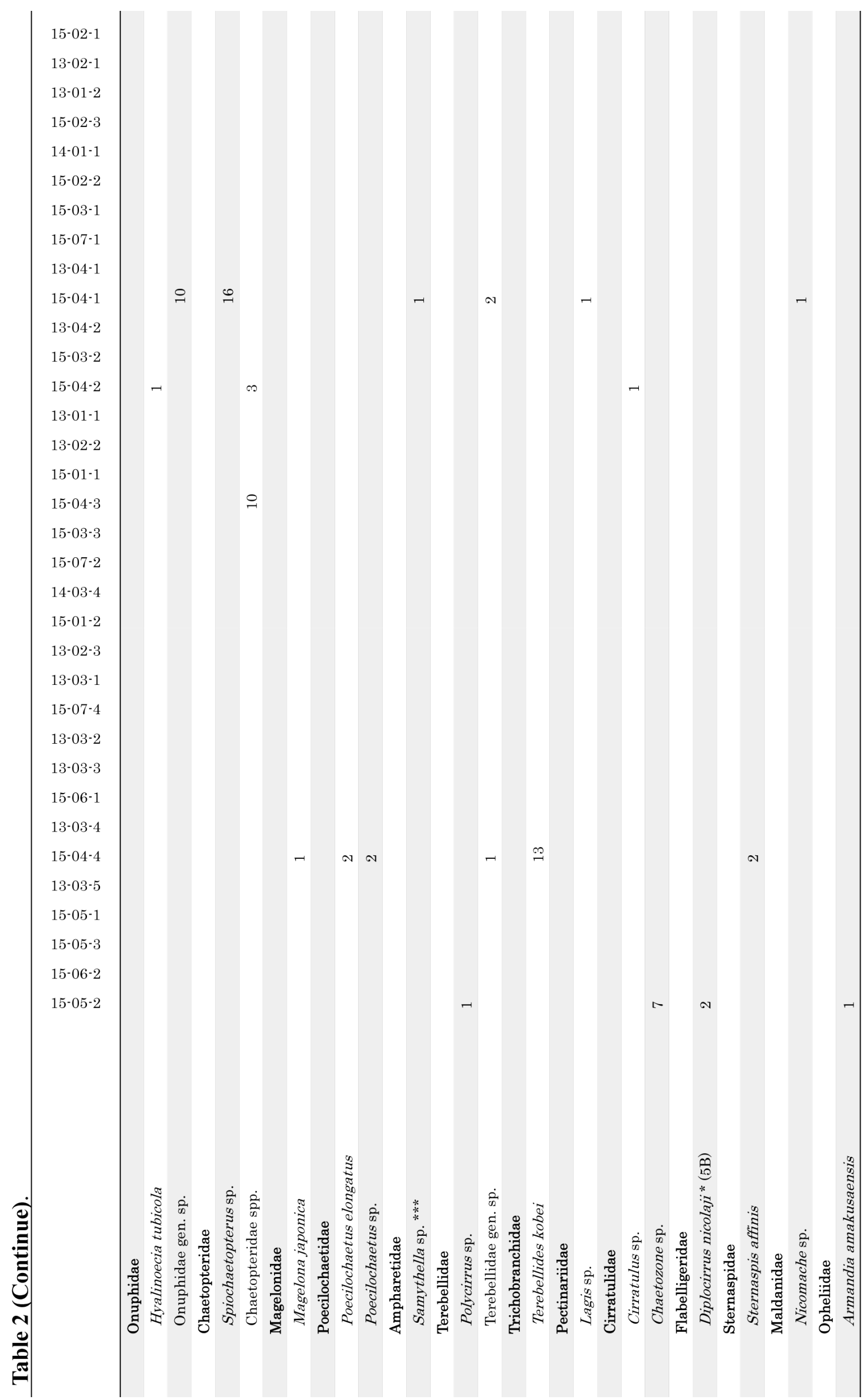


MASANORI OKANISHI ET AL.

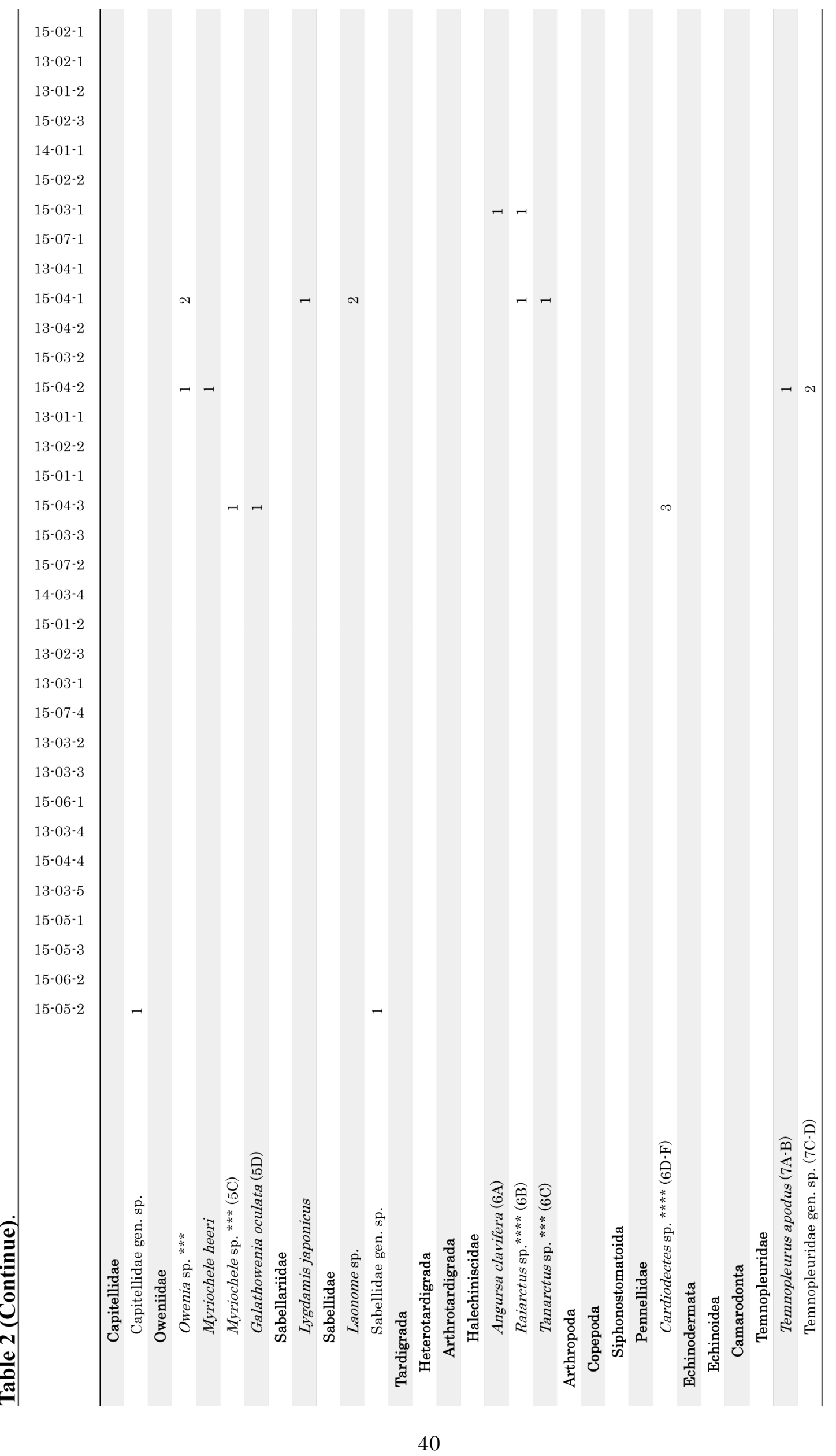


BENTHIC FAUNA OF SHIRAHAMA

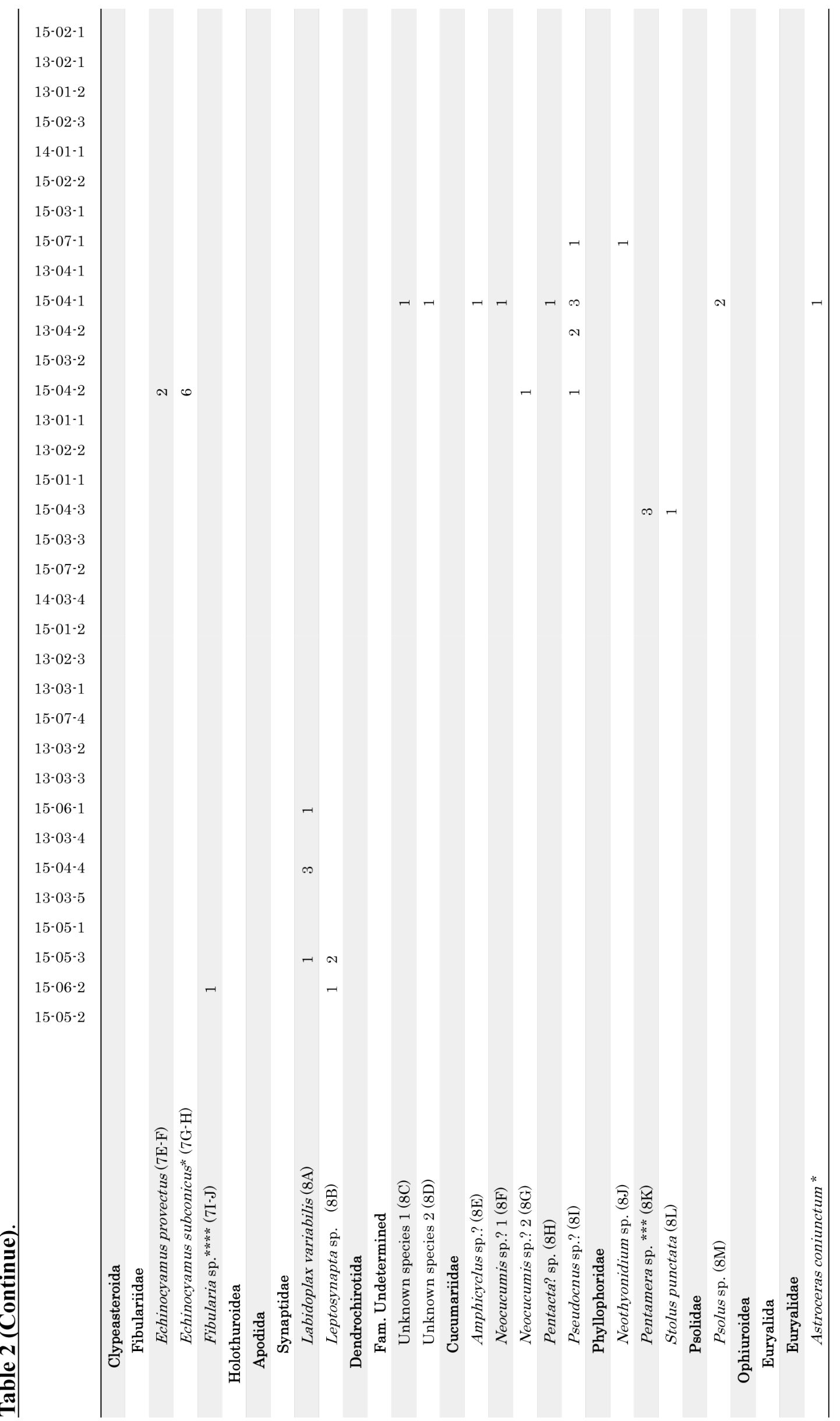


MASANORI OKANISHI ET AL.

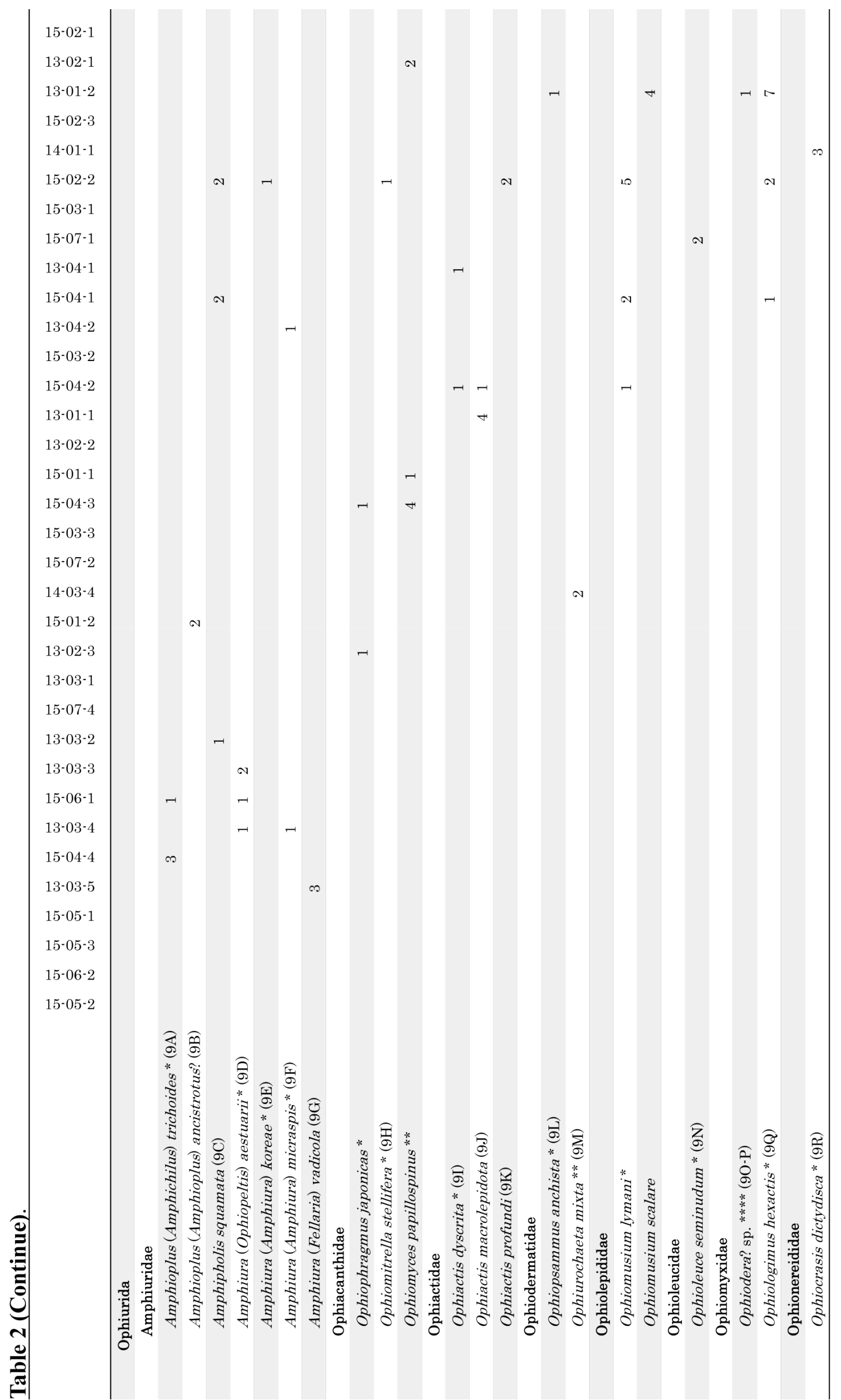


BENTHIC FAUNA OF SHIRAHAMA

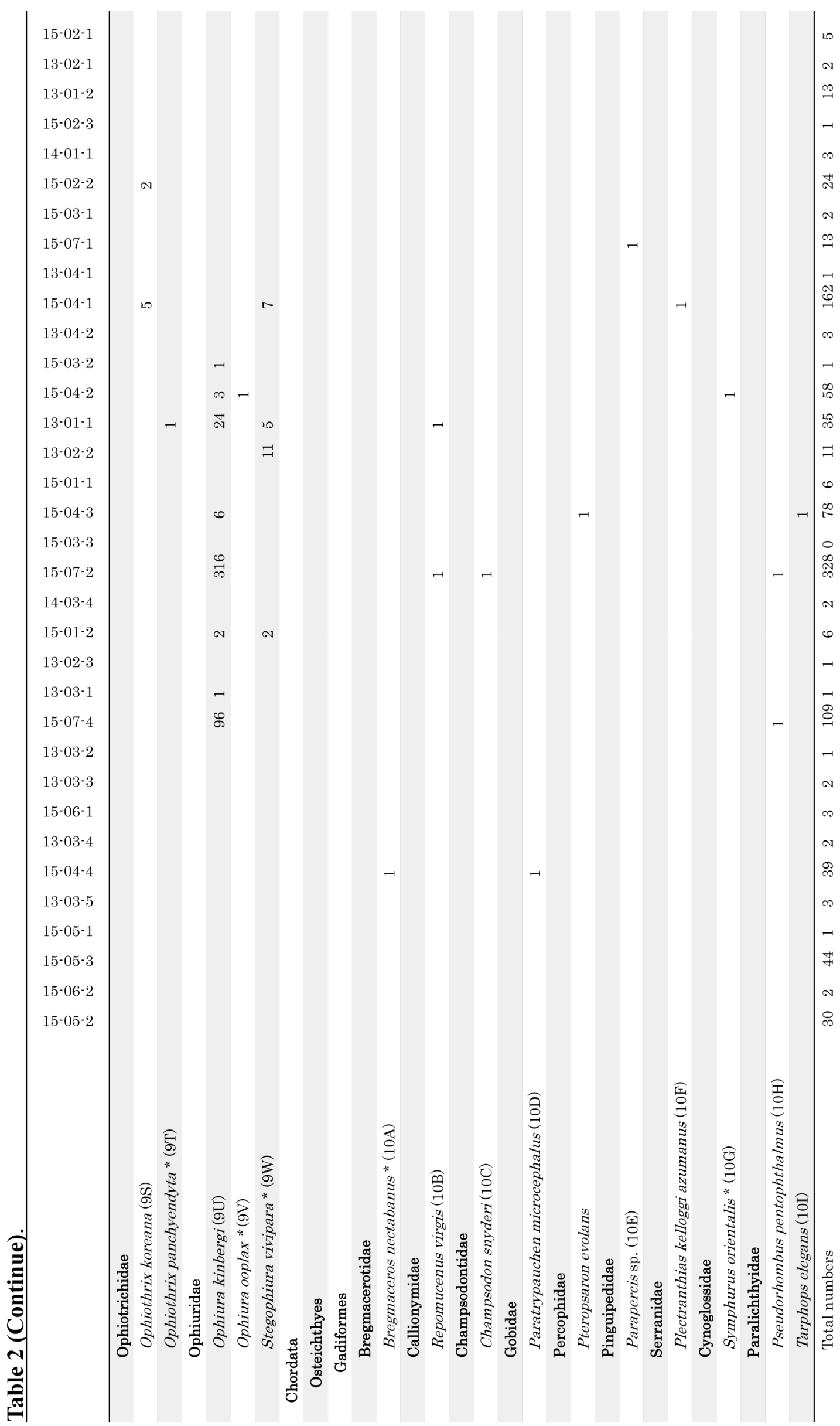



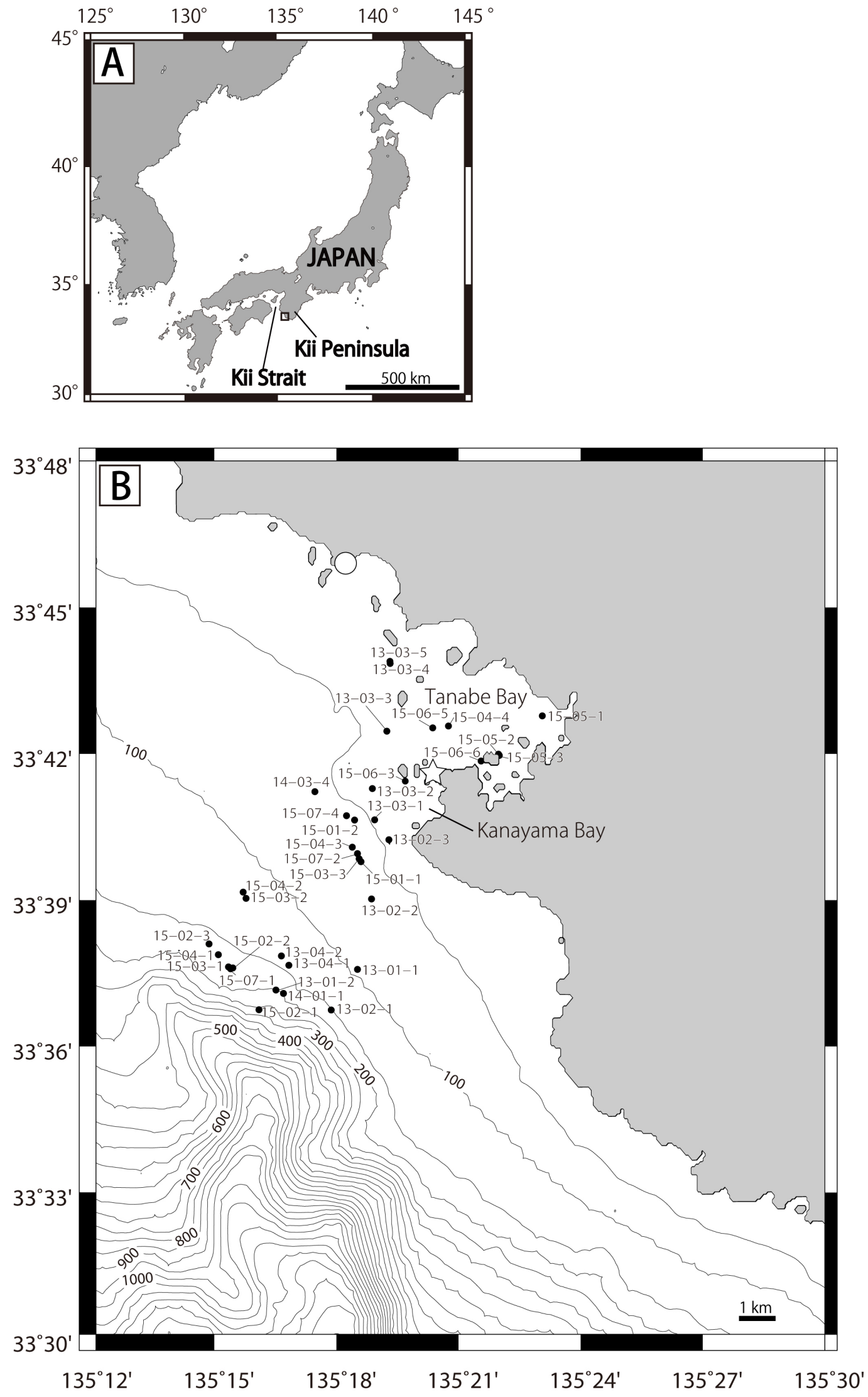

Figure 1. Survey area of the present study. A, a map of Japan. Shirahama Area is indicated by a square. B, SMR sampling sites (black dots). A star indicates Seto Marine Biological Laboratory and a circle indicates Sakai fishery port. Fig. B generated using GMT5 (Wessel et al., 2013) and ETOPO1 (Amante and Eakins, 2009). 


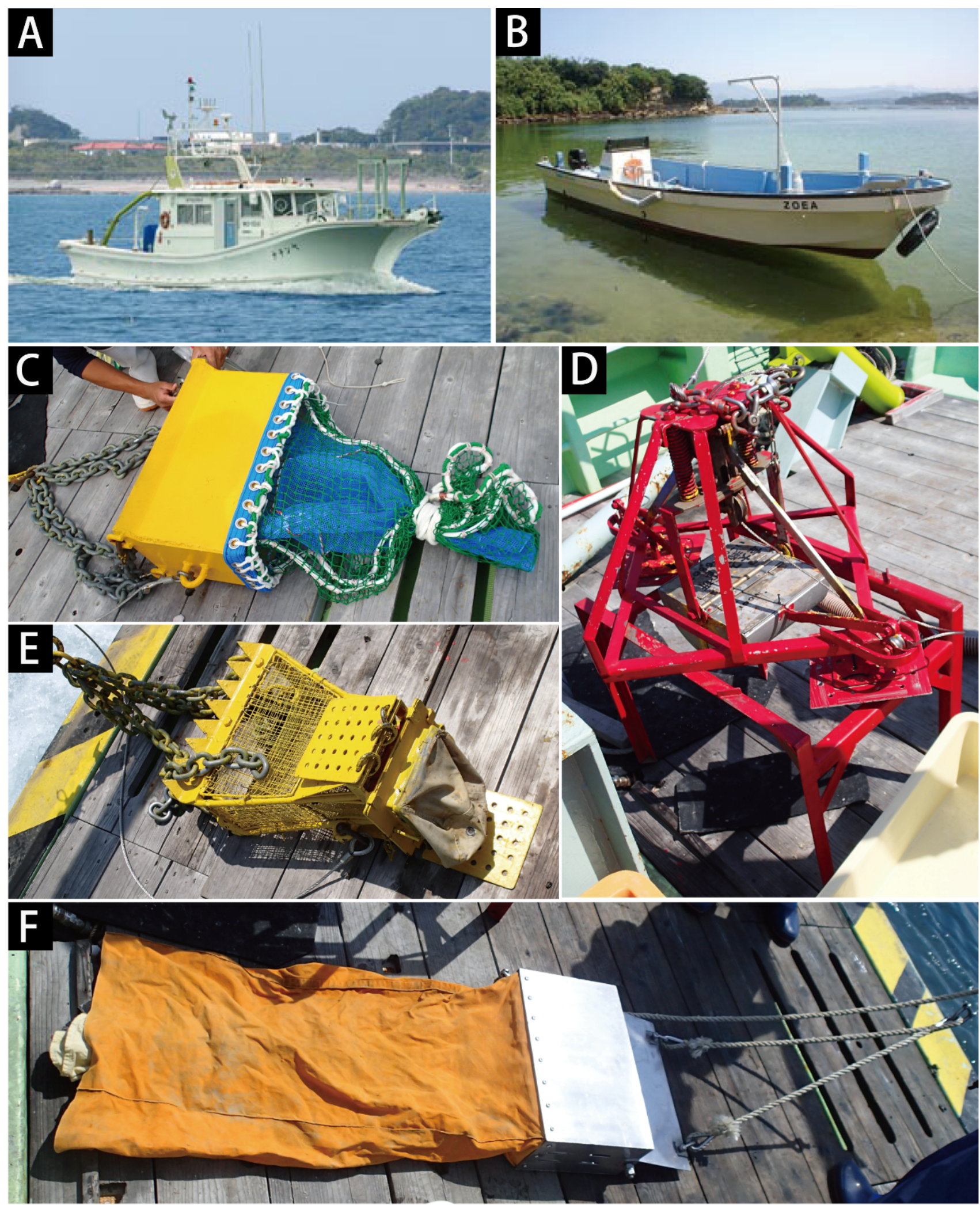

Figure 2. Vessels and sampling gears used in SMR. A, B: Research vessels of SMBL, Janthina (A) and Zoea (B). C-F: Sampling gears, $50 \mathrm{~cm}$-front biological dredge (C), Smith-Mcintyr bottom grab sampler, (D), Kamiya-type dredge (E), Dredge for meio-benthos (F). 


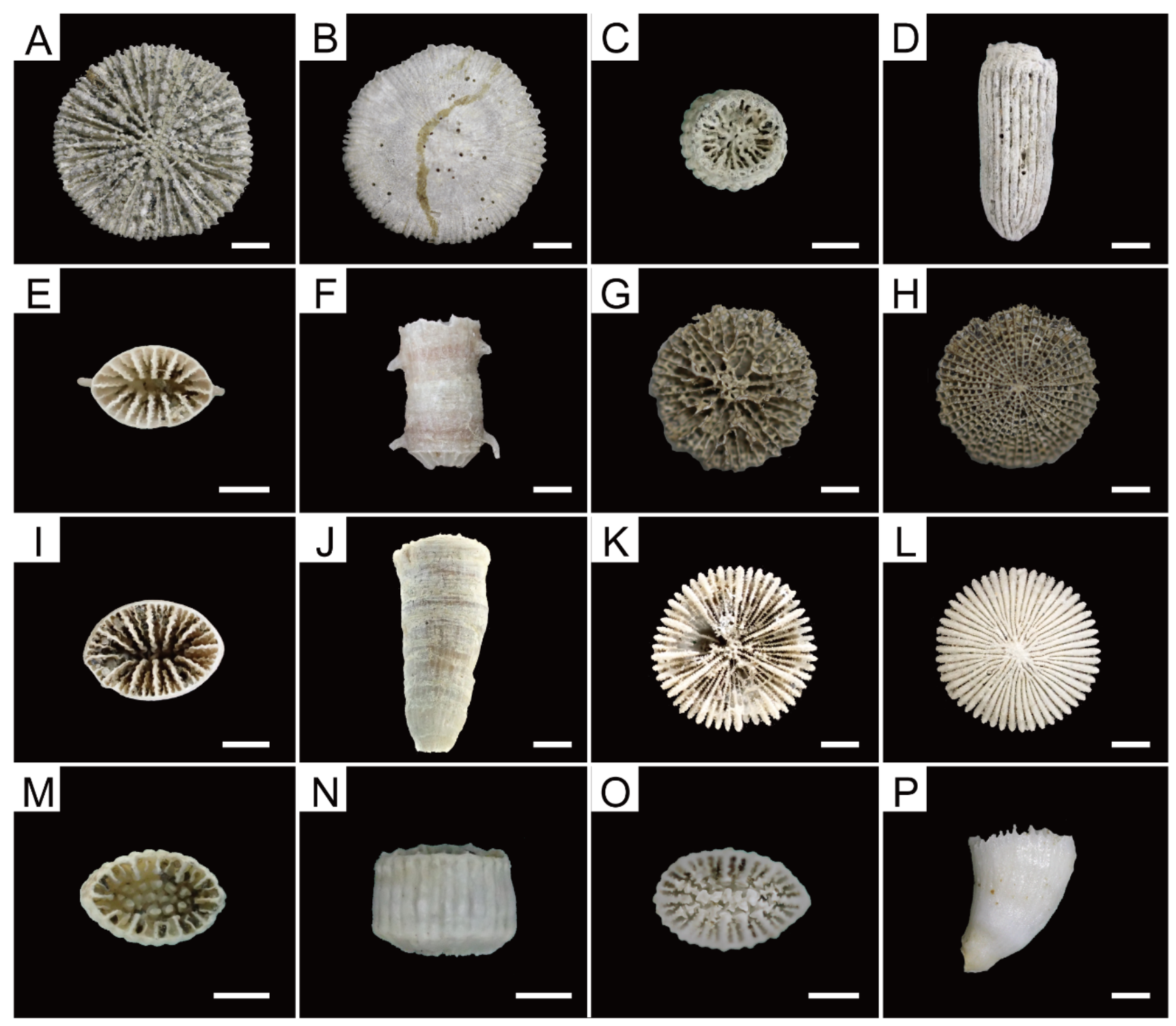

Figure 3. Cnidaria, Hexacolrallia. A-B. Anthemiphyllia dentate. C-D. Premocyathus dentiformis. E-F. Truncatoflabellum phoenix. G-H. Letepsammia formosissima. I-J. Truncatoguynia irregularis. K-L. Deltocyathoides orientalis. M-N. Idiotrochus kikutii. O-P. Peponocyathus folliculus. Scale bars = $2 \mathrm{~mm}$. 

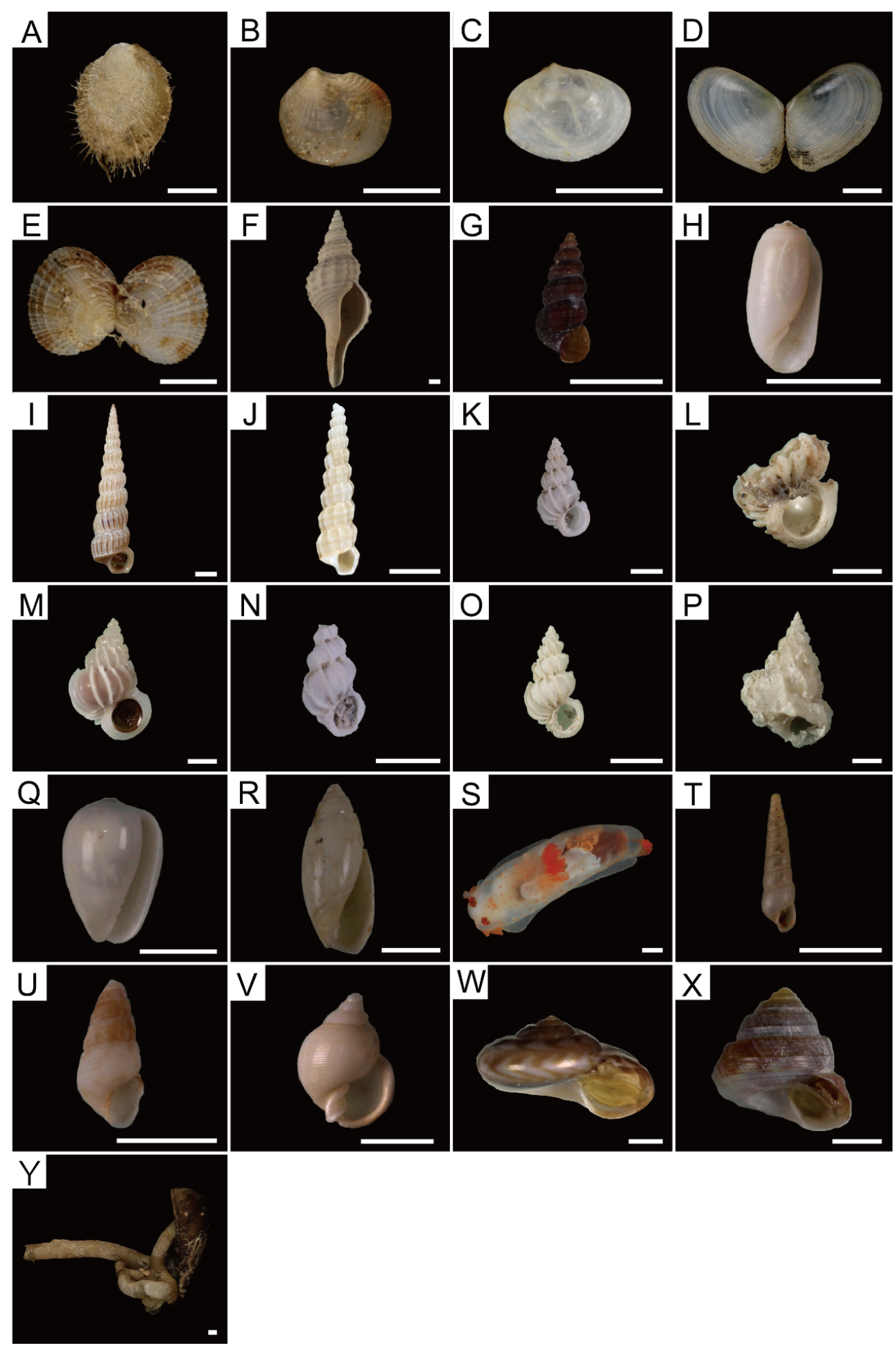

Figure 4. Mollusca, Bivalvia (A-E) and Gastropoda (F-Y). A. Nipponolimopsis azumana. B. Nipponolimopsis decussata. C. Cadella delta. D. Nitidotellina lischkei. E. Timoclea minuta. F. Granulifusus niponicus. G. Finella purpureoapicata. H. Decorifer insignis. I. Amaea dorysa. J. Cylindriscala sp. K. Epitonium angustum. L. Epitonium heloris. M. Epitonium liliputanum. N. Epitonium rimbogai. O. Epitonium simplex. P. Epitonium pallasi. Q. Gibberula novemprovincialis. R. Olivella fulgurata. S. Gymnodoris sp. T. Ptycheulimella misella. U. Odetta lirata. V. Ringicula tosaensis. W. Microgaza fulgens. X. Minolia subangulata. Y. Thylacodes medusa. Scale bars $=2 \mathrm{~mm}$. 


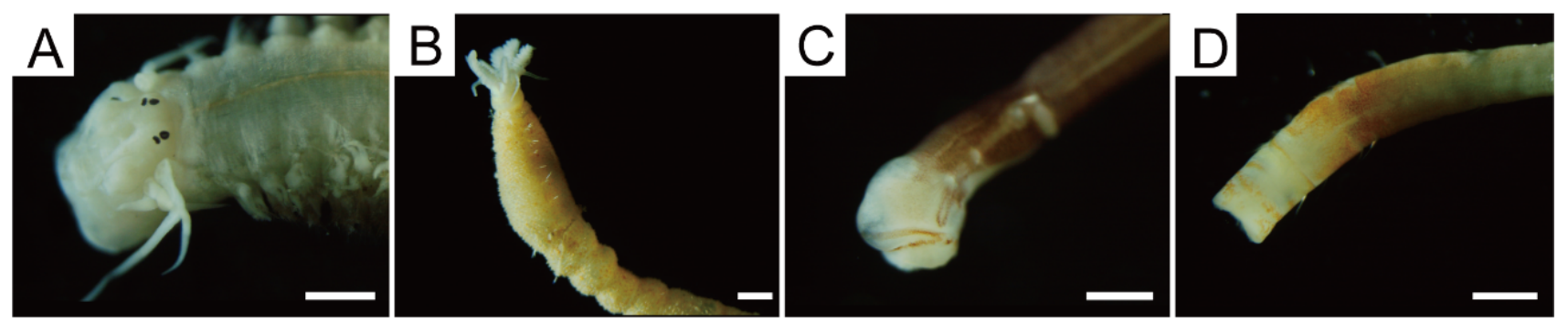

Figure 5. Annelida, polychaetes, anterior end. A. Tambalagamia fauveli. B. Diplocirrus nicolaji. C. Myriochele sp. D. Galathowenia oculata. Scale bars $=0.5 \mathrm{~mm}$.
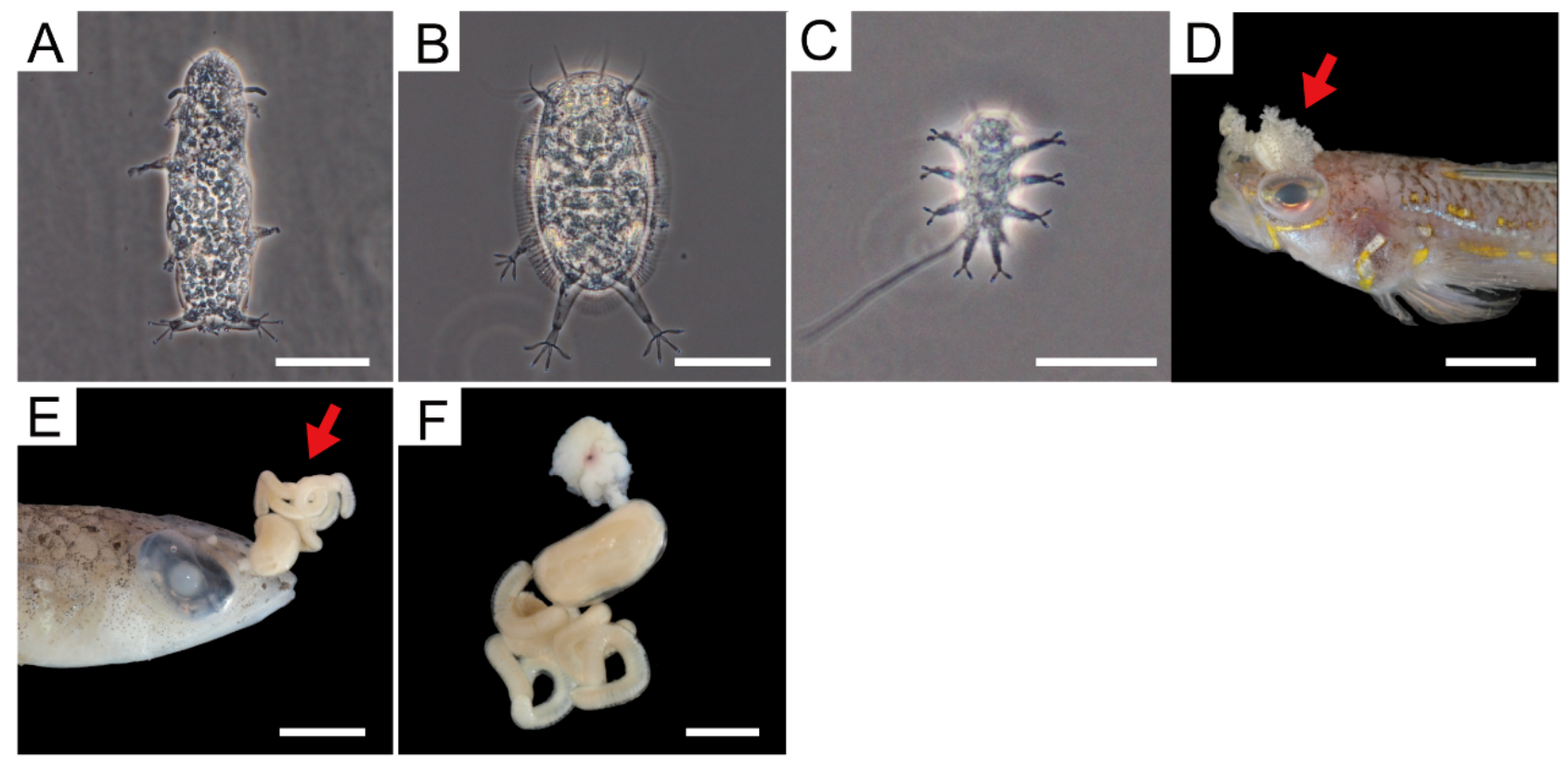

Figure 6. Tardigrada, Heterotardigrada (A-C) and Arthropoda, Copepoda (D-F). A. Angursa clavifera. B.

Raiarctus sp. C. Tanarctus sp. D-F. Cardiodectes sp., parasitic on an eye of Pteropsaron evolans, indicated by an arrow, collected in SMR 15-04-3 (D), on an eye of Osopsaron formosense, indicated by an arrow (E), and a separated individual, dorsal view (F), collected in SMR 16-01-1. Scale bars $=50 \mu \mathrm{m}(\mathrm{A}-\mathrm{C}), 5 \mathrm{~mm}$ (D), $2 \mathrm{~mm}(\mathrm{E}), 1 \mathrm{~mm}(\mathrm{~F})$. 


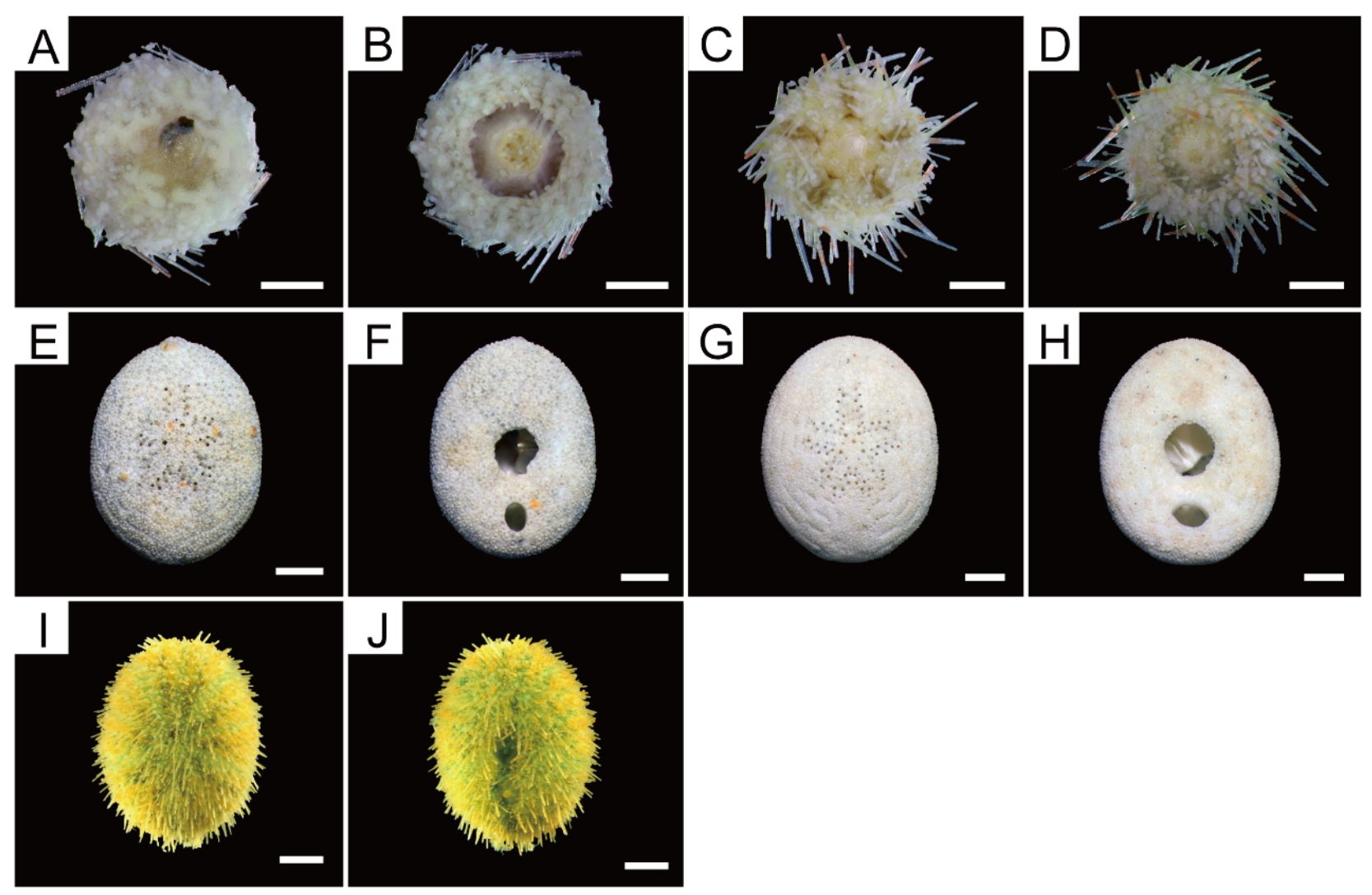

Figure 7. Echinodermata, Echinoidea. A-B. aboral and oral side views of Temnopleurus apodus. C-D. aboral and oral side views of Temnopleuroidae sp. gen. E-F. aboral and oral side views of Echinocyamus provectus. G-H. aboral and oral side views of Echinocyamus subconicus. I-J. aboral and oral side views of Fibularia sp. Scale bars $=1 \mathrm{~mm}$. 


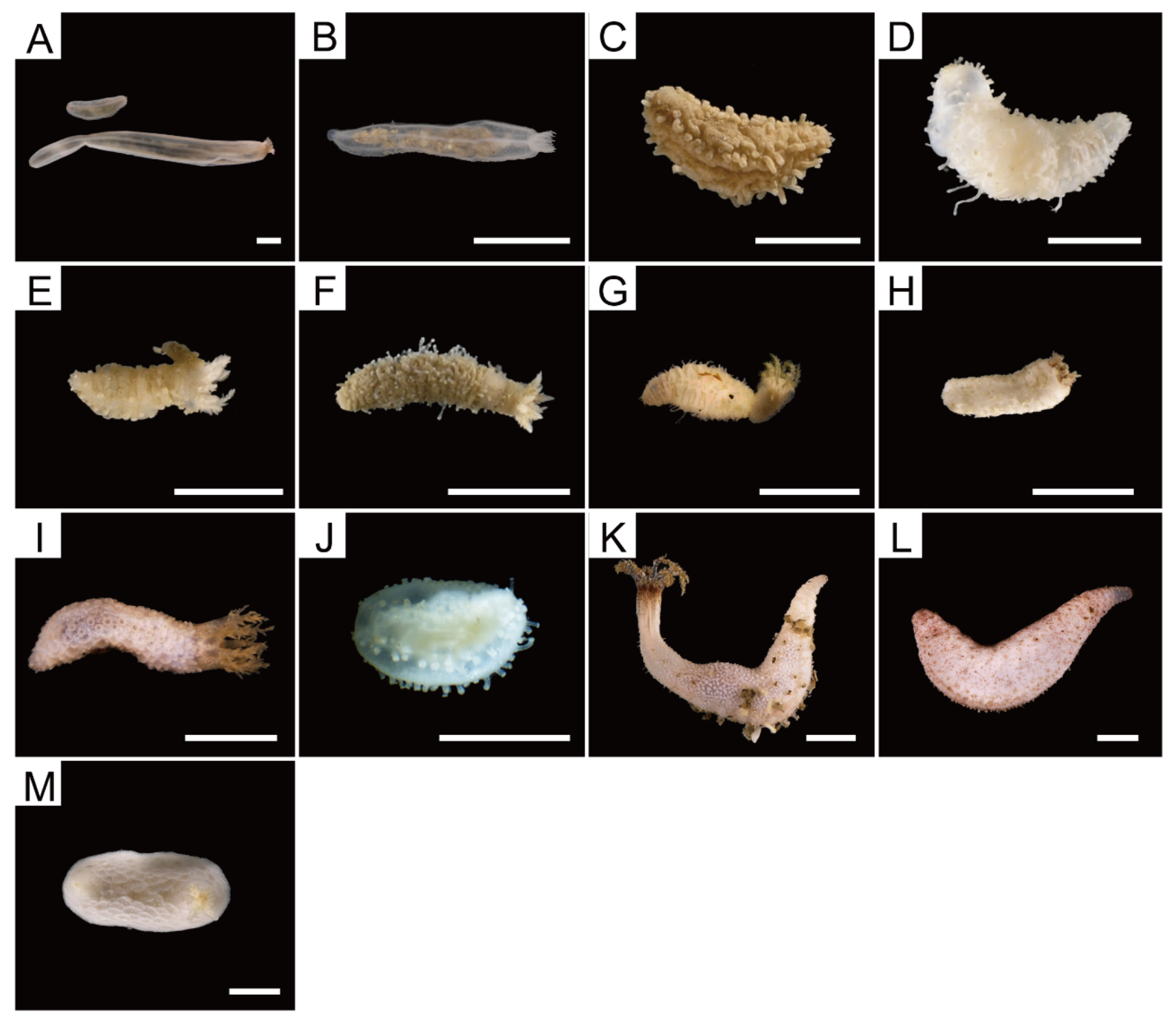

Figure 8. Echinodermata, Holothuroidea. A. lateral view of Labidoplax variabilis. B. lateral view of Leptosynapta sp. C. lateral view of unknown species 1. D. lateral view of unknown species 2. E. lateral view of Amphicyclus sp.? F. lateral view of Neocucumis sp.? 1. G. lateral view of Neocucumis sp.? 2. H. dorsal view of Pentacta? sp. I. lateral view of Pseudocnus sp.? J. lateral view of Neothyonidium sp. K. lateral view of Pentamera sp. L. lateral view of Stolus punctata. M. dorsal view of Psolus sp. Scale bars $=5$ $\mathrm{mm}$. 


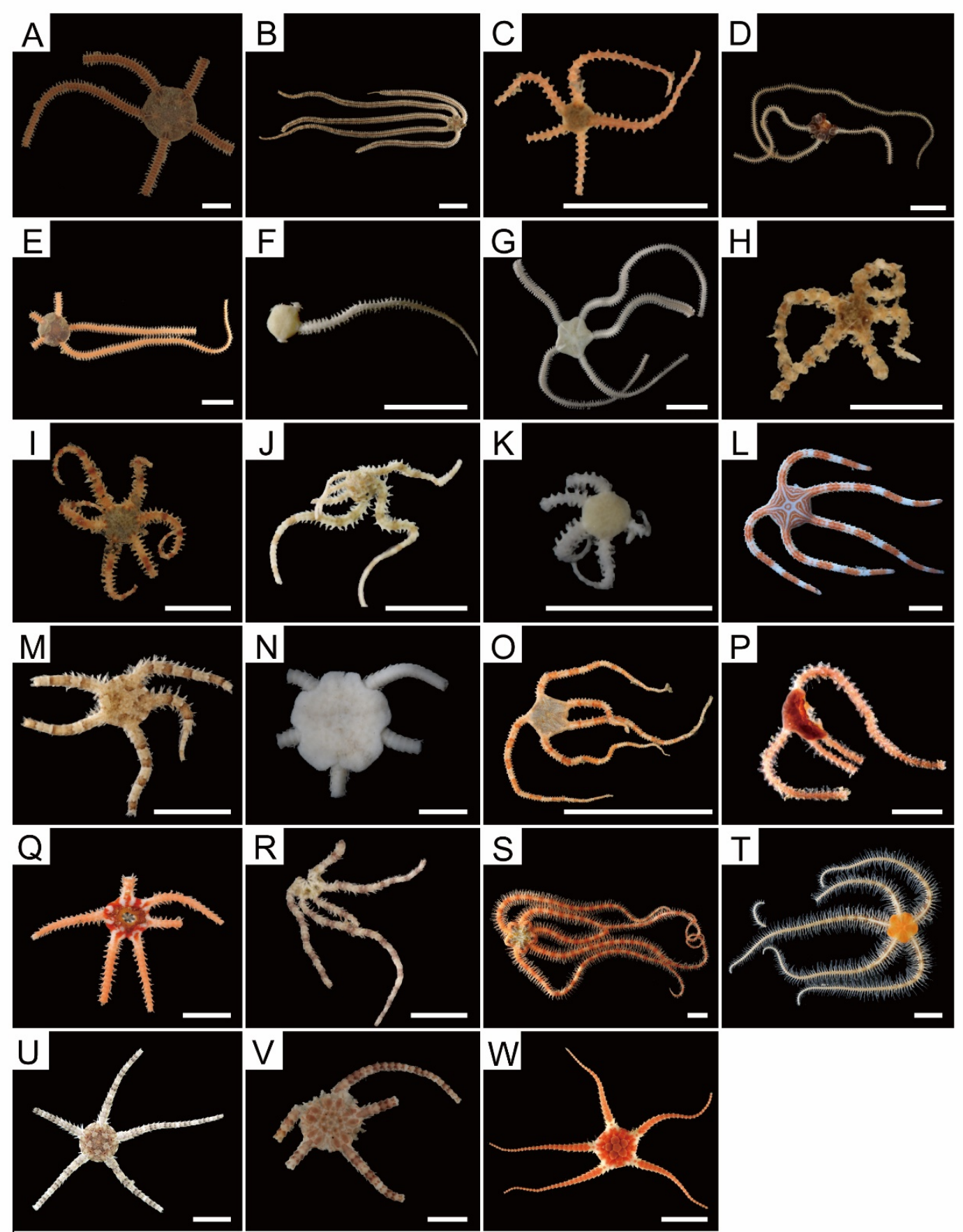

Figure 9. Echinodermata, Ophiuroidea, aboral views. A. Amphioplus (Amphichilus) trichoides. B. Amphioplus (Amphioplus) ancistrotus?. C. Amphipholis squamata. D. Amphiura (Ophiopeltis) aestuarii. E. Amphiura (Ophiopeltis) koreae. F. Amphiura (Amphiura) micraspis. G. Amphiura (Fellaria)vadicola.. H. Ophiomitrella stellifera. I. Ophiactis dyscrita. J. Ophiactis macrolepidota. K. Ophiactis profundi. L. Ophiopsammus anchista. M. Ophiurochaeta mixta. N. Ophioleuce seminudum. O, P. Ophiodera? sp. Adult (O) and juvenile (P). Q, Ophiologimus hexactis. R. Ophiocrasis dictydisca. S. Ophiothrix koreana. T. Ophiothrix panchyendyta. U. Ophiura kinbergi. V. Ophiura ooplax. W. Stegophiura vivipara. Scale bars = $5 \mathrm{~mm}$. 


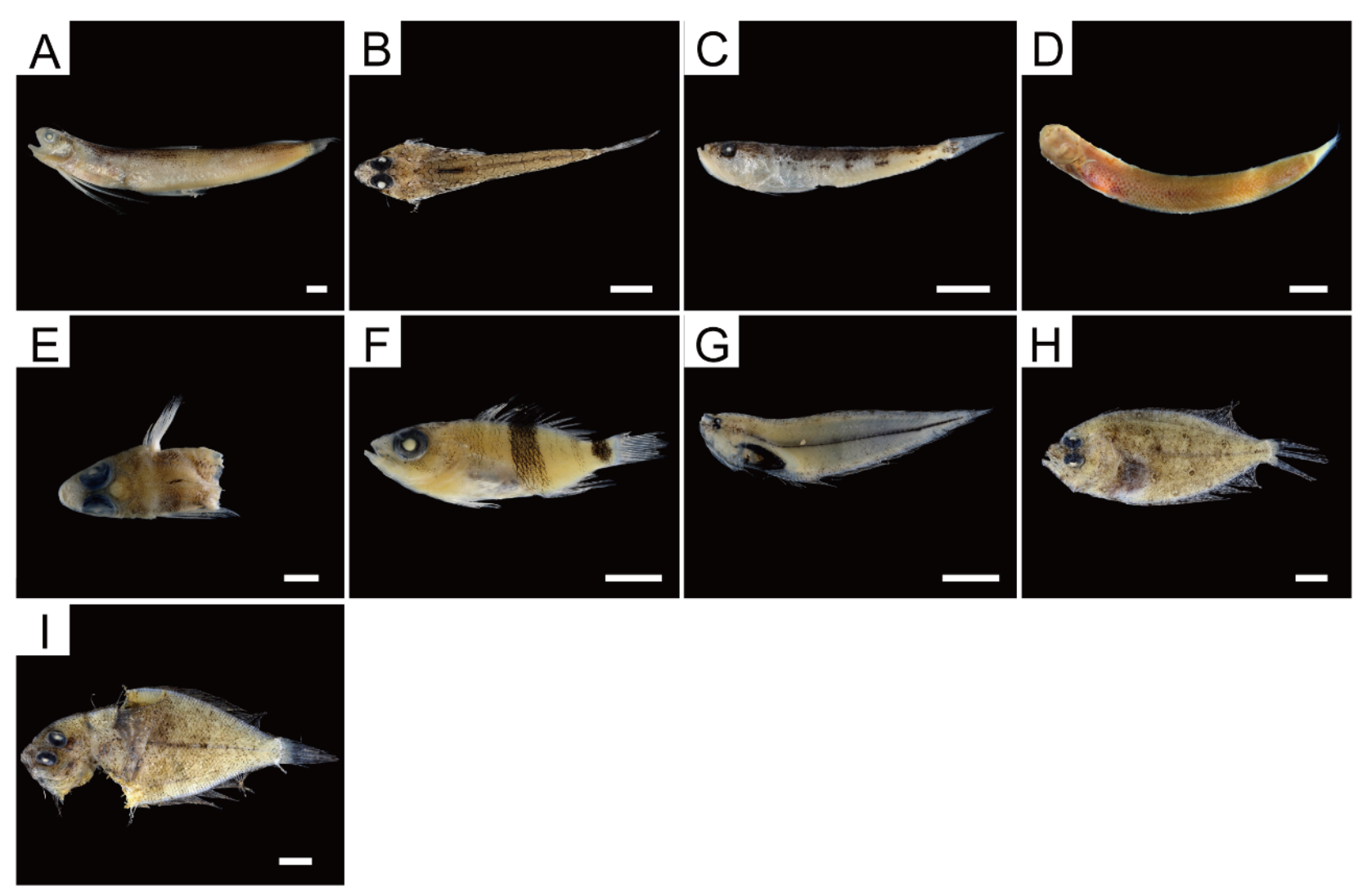

Figure 10. Chordata, Osteichthyes. A. lateral view of Bregmaceros nectabanus. B. dorsal view of Repomucenus virgis. C. lateral view of Champsodon snyderi. D. lateral view of Paratrypauchen microcephalus. E. dorsal view of Parapercis sp. F. lateral view of Plectranthias kelloggi azumanus. G. lateral view of Symphurus orientalis. H. lateral view of Pseudorhombus pentophthalmus. I. lateral view of Tarphops elegans. Scale bars $=5 \mathrm{~mm}$. 